4

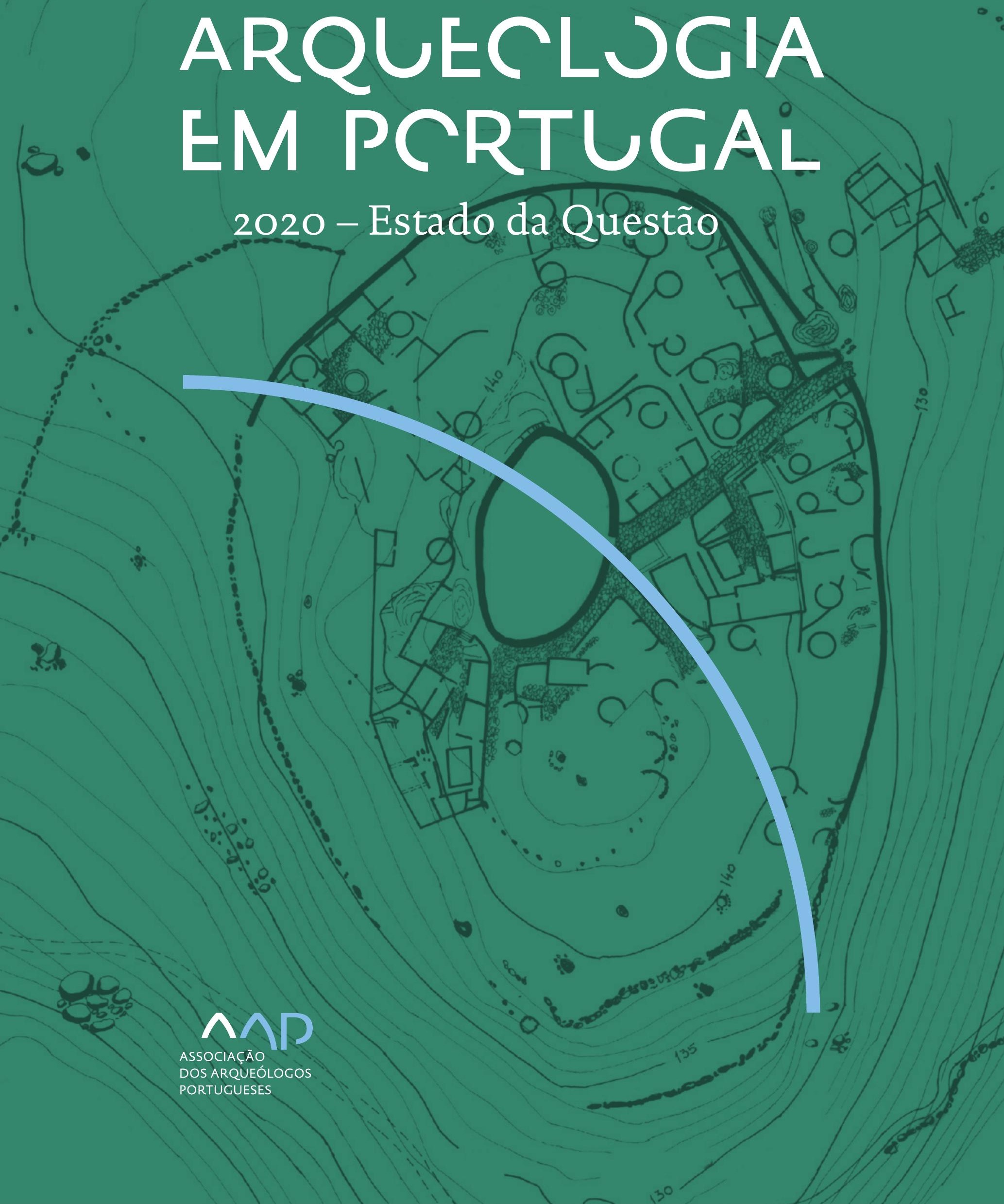


Coordenação editorial: José Morais Arnaud, César Neves e Andrea Martins Design gráfico: Flatland Design

AAP - ISBN: 978-972-9451-89-8

CITCEM - ISBN: 978-989-8970-25-1

Associação dos Arqueólogos Portugueses e CITCEM

Lisboa, 2020

O conteúdo dos artigos é da inteira responsabilidade dos autores. Sendo assim a Associação dos Arqueólogos Portugueses declina qualquer responsabilidade por eventuais equívocos ou questões de ordem ética e legal.

Desenho de capa:

Planta do castro de Monte Mozinho (Museu Municipal de Penafiel).

\section{$\hat{\wedge} \mathrm{P}$}

DOS ARQUEÓLOGOS PORTUGUESES

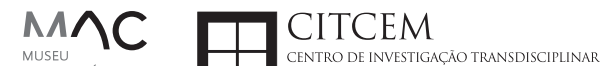
MUSEU
ARQUELLÓGICO
DO CARMO
U.PORTO

FLUP FACULDADE DE LETRAS
UNIVERSIDADE DO PORTO

Apoio

EC para a Ciência 


\section{Índice}

15 Prefácio

José Morais Arnaud

\section{Historiografia e Teoria}

17 Território, comunidade, memória e emoção: a contribuição da história da arqueologia (algumas primeiras e breves reflexões)

Ana Cristina Martins

25 Como descolonizar a arqueologia portuguesa?

Rui Gomes Coelho

41 Arqueologia e Modernidade: uma revisitação pessoal e breve de alguns aspetos da obra homónima de Julian Thomas de 2004

Vítor Oliveira Jorge

57 Dados para a História das Mulheres na Arqueologia portuguesa, dos finais do século XIX aos inícios do século XX: números, nomes e tabelas

Filipa Dimas / Mariana Diniz

73 Retractos da arqueologia portuguesa na imprensa: (in)visibilidades no feminino

Catarina Costeira / Elsa Luís

85 Arqueologia e Arqueólogos no Norte de Portugal Jacinta Bugalhão

101 Vieira Guimarães (1864-1939) e a arqueologia em Tomar: uma abordagem sobre o território e as gentes

João Amendoeira Peixoto / Ana Cristina Martins

115 Os memoráveis? A arqueologia algarvia na imprensa nacional e regional na presente centúria (2001-2019): características, visões do(s) passado(s) e a arqueologia

enquanto marca

Frederico Agosto / João Silva

129 A Evolução da Arqueologia Urbana e a Valorização Patrimonial no Barlavento Algarvio: Os casos de Portimão e Silves

Artur Mateus / Diogo Varandas / Rafael Boavida

\section{Gestão, Valorização e Salvaguarda do Património}

145 O Caderno Reivindicativo e as condições de trabalho em Arqueologia Miguel Rocha / Liliana Matias Carvalho / Regis Barbosa / Mauro Correia / Sara Simões / Jacinta Bugalhão / Sara Brito / Liliana Veríssimo Carvalho / Richard Peace / Pedro Peça / Cézer Santos

155 Os Estudos de Impacte Patrimonial como elemento para uma estratégia sustentável de minimização de impactes no âmbito de reconversões agrícolas Tiago do Pereiro

165 Salvaguarda de Património arqueológico em operações florestais: gestão e sensibilização Filipa Bragança / Gertrudes Zambujo / Sandra Lourenço / Belém Paiva / Carlos Banha / Frederico Tatá Regala / Helena Moura / Jacinta Bugalhão / João Marques / José Correia / Pedro Faria / Samuel Melro

179 Os valores do Património: uma investigação sobre os Sítios Pré-históricos de Arte Rupestre do Vale do Rio Côa e de Siega Verde José Paulo Francisco 
189 Conjugando recursos arqueológicos e naturais para potenciar as visitas ao Geoparque Litoral de Viana do Castelo (Noroeste de Portugal)

Hugo A. Sampaio / Ana M.S. Bettencourt / Susana Marinho / Ricardo Carvalhido

203 Áreas de Potencial Arqueológico na Região do Médio Tejo: Modelo Espacial Preditivo Rita Ferreira Anastácio / Ana Filipa Martins / Luiz Oosterbeek

223 Património Arqueológico e Gestão Territorial: O contributo da Arqueologia para a revisão do PDM de Avis

Ana Cristina Ribeiro

237 A coleção arqueológica do extinto Museu Municipal do Porto - Origens, Percursos e Estudos

Sónia Couto

251 Valpaços - uma nova carta arqueológica

Pedro Pereira / Maria de Fátima Casares Machado

263 Arqueologia na Cidade de Peniche

Adriano Constantino / Luís Rendeiro

273 Arqueologia Urbana: a cidade de Lagos como caso de Estudo Cátia Neto

285 Estratégias de promoção do património cultural subaquático nos Açores. O caso da ilha do Faial

José Luís Neto / José Bettencourt / Luís Borges / Pedro Parreira

297 Carta Arqueológica da Cidade Velha: Uma primeira abordagem

Jaylson Monteiro / Nireide Tavares / Sara da Veiga / Claudino Ramos / Edson Brito /

Carlos Carvalho / Francisco Moreira / Adalberto Tavares

311 Antropologia Virtual: novas metodologias para a análise morfológica e funcional Ricardo Miguel Godinho / Célia Gonçalves

\section{Didáctica da Arqueologia}

327 Como os projetos de Arqueologia podem contribuir para uma comunidade culturalmente mais consciente Alexandra Figueiredo / Claúdio Monteiro / Adolfo Silveira / Ricardo Lopes

337 Educação Patrimonial - Um cidadão esclarecido é um cidadão ativo! Ana Paula Almeida

351 A aproximação da Arqueologia à sala de aula: um caso de estudo no $3^{\circ}$ ciclo do Ensino Básico Luís Serrão Gil

363 Arqueologia 3.o - Pensar e comunicar a Arqueologia para um futuro sustentável Mónica Rolo

377 “Conversa de Arqueólogos" - Divulgar a Arqueologia em tempos de Pandemia Diogo Teixeira Dias

389 Escola Profissional de Arqueologia: desafios e oportunidades Susana Nunes / Dulcineia Pinto / Júlia Silva / Ana Mascarenhas

399 Os Museus de Arqueologia e os Jovens: a oferta educativa para o público adolescente Beatriz Correia Barata / Leonor Medeiros

411 O museu universitário como mediador entre a ciência e a sociedade: o exemplo da secção de arqueologia no Museu de História Natural e da Ciência da Universidade do Porto (MHNC-UP)

Rita Gaspar 
421 Museu de Lanifícios: Real Fábrica de Panos. Atividades no âmbito da Arqueologia Beatriz Correia Barata / Rita Salvado

427 Arqueologia Pública e o caso da localidade da Mata (Torres Novas) Cláudia Manso / Ana Rita Ferreira / Cristiana Ferreira / Vanessa Cardoso Antunes

431 Do sítio arqueológico ao museu: um percurso (também) didático Lídia Fernandes

447 Estão todos convidados para a Festa! E para dançar também... O projecto do Serviço Educativo do Museu Arqueológico do Carmo na $5^{\underline{a}}$ Edição da Festa da Arqueologia Rita Pires dos Santos

459 O “Clã de Carenque”, um projeto didático de arqueologia Eduardo Gonzalez Rocha

469 Mediação cultural: peixe que puxa carroça nas Ruínas Romanas de Troia Inês Vaz Pinto / Ana Patrícia Magalhães / Patrícia Brum / Filipa Santos

481 Didática Arqueológica, experiências do Projeto Mértola Vila Museu Maria de Fátima Palma / Clara Rodrigues / Susana Gómez / Lígia Rafael

\section{Arte Rupestre}

497 Os inventários de arte rupestre em Portugal Mila Simões de Abreu

513 O projeto FIRST-ART - conservação, documentação e gestão das primeiras manifestações de arte rupestre no Sudoeste da Península Ibérica: as grutas do Escoural e Maltravieso Sara Garcês / Hipólito Collado / José Julio García Arranz / Luiz Oosterbeek / António Carlos Silva / Pierluigi Rosina / Hugo Gomes / Anabela Borralheiro Pereira / George Nash / Esmeralda Gomes / Nelson Almeida / Carlos Carpetudo

523 Trabalhos de documentação de arte paleolítica realizados no âmbito do projeto PalæoCôa André Tomás Santos / António Fernando Barbosa / Luís Luís / Marcelo Silvestre / Thierry Aubry

537 Imagens fantasmagóricas, silhuetas elusivas: as figuras humanas na arte do Paleolítico Superior da região do Côa Mário Reis

$55^{1}$ Os motivos zoomórficos representados nas placas de tear de Vila Nova de São Pedro (Azambuja, Portugal) Andrea Martins / César Neves / José M. Arnaud / Mariana Diniz

571 Arte Rupestre do Monte de Góios (Lanhelas, Caminha). Síntese dos resultados dos trabalhos efectuados em 2007-2009 Mário Varela Gomes

599 Gravuras rupestres de barquiformes no Monte de S. Romão, Guimarães, Noroeste de Portugal Daniela Cardoso

613 Círculos segmentados gravados na Bacia do Rio Lima (Noroeste de Portugal): contributos para o seu estudo Diogo Marinho / Ana M.S. Bettencourt / Hugo Aluai Sampaio

631 Equídeos gravados no curso inferior do Rio Mouro, Monção (NW Portugal). Análise preliminar Coutinho, L.M. / Bettencourt, A.M.S / Sampaio, Hugo A.S

645 Paletas na Arte Rupestre do Noroeste de Portugal. Inventário preliminar Bruna Sousa Afonso / Ana M. S. Bettencourt / Hugo A. Sampaio 


\section{Pré-História}

661 O projeto Miño/Minho: balanço de quatro anos de trabalhos arqueológicos Sérgio Monteiro-Rodrigues / João Pedro Cunha-Ribeiro / Eduardo Méndez-Quintas / Carlos Ferreira / Pedro Xavier / José Meireles / Alberto Gomes / Manuel Santonja / Alfredo Pérez-González

677 A ocupação paleolítica da margem esquerda do Baixo Minho: a indústria lítica do sítio de Pedreiras 2 (Monção, Portugal) e a sua integração no contexto regional Carlos Ferreira / João Pedro Cunha-Ribeiro / Sérgio Monteiro-Rodrigues / Eduardo Méndez-Quintas / Pedro Xavier / José Meireles / Alberto Gomes / Manuel Santonja / Alfredo Pérez-González

693 O sítio acheulense do Plistocénico médio da Gruta da Aroeira Joan Daura / Montserrat Sanz / Filipa Rodrigues / Pedro Souto / João Zilhão

703 As sociedades neandertais no Barlavento algarvio: modelos preditivos com recurso aos SIG

Daniela Maio

715 A utilização de quartzo durante o Paleolítico Superior no território dos vales dos rios Vouga e Côa

Cristina Gameiro / Thierry Aubry / Bárbara Costa / Sérgio Gomes / Luís Luís / Carmen Manzano / André Tomás Santos

733 Uma perspetiva diacrónica da ocupação do concheiro do Cabeço da Amoreira (Muge, Portugal) a partir da tecnologia lítica Joana Belmiro / João Cascalheira / Célia Gonçalves

745 Novos dados sobre a Pré-história Antiga no concelho de Palmela. A intervenção arqueológica no sítio do Poceirão I

Michelle Teixeira Santos

757 Problemas em torno de Datas Absolutas Pré-Históricas no Norte do Alentejo Jorge de Oliveira

771 Povoamento pré-histórico nas áreas montanhosas do NO de Portugal: o Abrigo 1 de Vale de Cerdeira Pedro Xavier / José Meireles / Carlos Alves

783 Apreciação do povoamento do Neolítico Inicial na Baixa Bacia do Douro. A Lavra I (Serra da Aboboreira) como caso de estudo Maria de Jesus Sanches

797 O Processo de Neolitização na Plataforma do Mondego: os dados do Sector C do Outeiro dos Castelos de Beijós (Carregal do Sal)

João Carlos de Senna-Martinez / José Manuel Quintã Ventura / Andreia Carvalho / Cíntia Maurício

823 Novos trabalhos na Lapa da Bugalheira (Almonda, Torres Novas) Filipa Rodrigues / Pedro Souto / Artur Ferreira / Alexandre Varanda / Luís Gomes / Helena Gomes / João Zilhão

837 A pedra polida e afeiçoada do sítio do Neolítico médio da Moita do Ourives (Benavente, Portugal)

César Neves

857 Casal do Outeiro (Encarnação, Mafra): novos contributos para o conhecimento do povoamento do Neolítico final na Península de Lisboa.

Cátia Delicado / Carlos Maneira e Costa / Marta Miranda / Ana Catarina Sousa

873 Stresse infantil, morbilidade e mortalidade no sítio arqueológico do Neolítico Final/ Calcolítico ( $4^{\circ}$ e $3^{\circ}$ milénio a.C.) do Monte do Carrascal 2 (Ferreira do Alentejo, Beja) Liliana Matias de Carvalho / Sofia N. Wasterlain 
885 Come together: O Conjunto Megalítico das Motas (Monção, Viana do Castelo) e as expressões Campaniformes do Alto Minho Ana Catarina Basílio / Rui Ramos

899 Trabalhos arqueológicos no sítio Calcolítico da Pedreira do Poio Carla Magalhães / João Muralha / Mário Reis / António Batarda Fernandes

913 O sítio arqueológico de Castanheiro do Vento. Da arquitectura do sítio à arquitectura de um território João Muralha Cardoso

925 Estudo zooarqueológico das faunas do Calcolítico final de Vila Nova de São Pedro (Azambuja, Portugal): Campanhas de 2017 e 2018 Cleia Detry / Ana Catarina Francisco / Mariana Diniz / Andrea Martins / César Neves / José Morais Arnaud

943 As faunas depositadas no Museu Arqueológico do Carmo provenientes de Vila Nova de São Pedro (Azambuja): as campanhas de 1937 a 1967 Ana Catarina Francisco / Cleia Detry / César Neves / Andrea Martins / Mariana Diniz / José Morais Arnaud

959 Análise funcional de material lítico em sílex do castro de Vila Nova de S. Pedro (Azambuja, Portugal): uma primeira abordagem Rafael Lima

971 O recinto da Folha do Ouro 1 (Serpa) no contexto dos recintos de fossos calcolíticos alentejanos

António Carlos Valera / Tiago do Pereiro / Pedro Valério / António M. Monge Soares

\section{Proto-História}

987 Produção de sal marinho na Idade do Bronze do noroeste Português. Alguns dados para uma reflexão

Ana M. S. Bettencourt / Sara Luz / Nuno Oliveira / Pedro P. Simões / Maria Isabel C. Alves / Emílio Abad-Vidal

1001 A estátua-menir do Pedrão ou de São Bartolomeu do Mar (Esposende, noroeste de Portugal) no contexto arqueológico da fachada costeira de entre os rios Neiva e Cávado Ana M. S. Bettencourt / Manuel Santos-Estévez / Pedro Pimenta Simões / Luís Gonçalves

1015 O Castro do Muro (Vandoma/Baltar, Paredes) - notas para uma biografia de ocupação da Idade do Bronze à Idade Média

Maria Antónia D. Silva / Ana M. S. Bettencourt / António Manuel S. P. Silva / Natália Félix

1031 Do Bronze Final à Idade Média - continuidades e hiatos na ocupação de Povoados em Oliveira de Azeméis João Tiago Tavares / Adriaan de Man

1041 As faunas do final da Idade do Bronze no Sul de Portugal: leituras desde o Outeiro do Circo (Beja)

Nelson J. Almeida / Íris Dias / Cleia Detry / Eduardo Porfírio / Miguel Serra

1055 A Espada do Monte das Oliveiras (Serpa) - uma arma do Bronze Pleno do Sudoeste Rui M. G. Monge Soares / Pedro Valério / Mariana Nabais / António M. Monge Soares

1065 São Julião da Branca (Albergaria-a-Velha) - Investigação e valorização de um povoado do Bronze Final

António Manuel S. P. Silva / Paulo A. P. Lemos / Sara Almeida e Silva / Edite Martins de Sá

1083 Do castro de S. João ao Mosteiro de Santa Clara: notícia de uma intervenção arqueológica, em Vila do Conde Rui Pinheiro 
1095 O castro de Ovil (Espinho), um quarto de século de investigação - resultados e questões em aberto

Jorge Fernando Salvador / António Manuel S. P. Silva

1111 O Castro de Salreu (Estarreja), um povoado proto-histórico no litoral do Entre Douro e Vouga

Sara Almeida e Silva / António Manuel S. P. Silva / Paulo A. P. Lemos / Edite Martins de Sá

1127 Castro de Nossa Senhora das Necessidades (Sernancelhe): uma primeira análise artefactual Telma Susana O. Ribeiro

${ }_{1141}$ A cividade de Bagunte. O estado atual da investigação Pedro Brochado de Almeida

1153 Zoomorfos na cerâmica da Idade do Ferro no NW Peninsular: inventário, cronologias e significado Nuno Oliveira / Cristina Seoane

1163 Vasos gregos em Portugal: diferentes maneiras de contar a história do intercâmbio cultural na Idade do Ferro

Daniela Ferreira

1175 Os exotica da necrópole da Idade do Ferro do Olival do Senhor dos Mártires (Alcácer do Sal) no seu contexto regional

Francisco B. Gomes

\section{Antiguidade Clássica e Tardia}

1191 O uso de madeira como combustível no sítio da Quinta de Crestelos (Baixo Sabor): da Idade do Ferro à Romanização Filipe Vaz / João Tereso / Sérgio Simões Pereira / José Sastre / Javier Larrazabal Galarza / Susana Cosme / José António Pereira / Israel Espi

1207 Cultivos de Época Romana no Baixo Sabor: continuidade em tempos de mudança? João Pedro Tereso / Sérgio Simões Pereira / Filipe Santos / Luís Seabra / Filipe Vaz

1221 A casa romana na Hispânia: aplicação dos modelos itálicos nas províncias ibéricas Fernanda Magalhães / Diego Machado / Manuela Martins

1235 As pinturas murais romanas da Rua General Sousa Machado, n. ${ }^{5}$ 1, Chaves José Carvalho

1243 Trás do Castelo (Vale de Mir, Pegarinhos, Alijó) - Uma exploração agrícola romana do Douro

Tony Silvino / Pedro Pereira

1255 A sequência de ocupação no quadrante sudeste de Bracara Augusta: as transformações de uma unidade doméstica Lara Fernandes / Manuela Martins

1263 Os Mosaicos com decoração geométrica e geométrico-vegetalista dos sítios arqueológicos da área do Conuentus Bracaraugustanus. Novas abordagens quanto à conservação, restauro, decoração e datação Maria de Fátima Abraços / Licínia Wrench

1277 “Casa Romana” do Castro de São Domingos (Cristelos, Lousada): Escavação, Estudo e Musealização Paulo André de P. Lemos

1291 A arqueobotânica no Castro de Guifões (Matosinhos, Noroeste de Portugal): O primeiro estudo carpológico

Luís Seabra / Andreia Arezes / Catarina Magalhães / José Varela / João Pedro Tereso 
1305 Um Horreum Augustano na Foz do Douro (Monte do Castelo de Gaia, Vila Nova de Gaia) Rui Ramos

1311 Ponderais romanos na Lusitânia: padrões, formas, materiais e contextos de utilização Diego Barrios Rodríguez

1323 Um almofariz centro-itálico na foz do Mondego

Marco Penajoia

1335 Estruturas romanas de Carnide - Lisboa Luísa Batalha / Mário Monteiro / Guilherme Cardoso

1347 O contexto funerário do sector da "necrópole NO" da Rua das Portas de S. Antão (Lisboa): o espaço, os artefactos, os indivíduos e a sua interconectividade na interpretação do passado Sílvia Loja, José Carlos Quaresma, Nelson Cabaço, Marina Lourenço, Sílvia Casimiro, Rodrigo Banha da Silva, Francisca Alves-Cardoso

${ }_{1361}$ Povoamento em época Romana na Amadora - resultados de um projeto pluridisciplinar Gisela Encarnação / Vanessa Dias

1371 A Arquitectura Residencial em Mirobriga (Santiago do Cacém): contributo a partir de um estudo de caso Filipe Sousa / Catarina Felício

${ }_{1385}$ O fim do ciclo. Saneamento e gestão de resíduos nos edifícios termais de Mirobriga (Santiago do Cacém)

Catarina Felício / Filipe Sousa

1399 Balsa, Topografia e Urbanismo de uma Cidade Portuária Vítor Silva Dias / João Pedro Bernardes / Celso Candeias / Cristina Tété Garcia

1413 No Largo das Mouras Velhas em Faro (2017): novas evidências da necrópole norte de Ossonoba e da sua ocupação medieval Ricardo Costeira da Silva / Paulo Botelho / Fernando Santos / Liliana Nunes

1429 Instrumentos de pesca recuperados numa fábrica de salga em Ossonoba (Faro) Inês Rasteiro / Ricardo Costeira da Silva / Paulo Botelho

1439 A Necrópole Romana do Eirô, Duas Igrejas (Penafiel): intervenção arqueológica de 2016 Laura Sousa / Teresa Soeiro

1457 Ritual, descarte ou afetividade? A presença de Canis lupus familiaris na Necrópole Noroeste de Olisipo (Lisboa)

Beatriz Calapez Santos / Sofia Simões Pereira / Rodrigo Banha da Silva / Sílvia Casimiro / Cleia Detry / Francisca Alves Cardoso

1467 Dinâmicas económicas em Bracara na Antiguidade Tardia Diego Machado / Manuela Martins / Fernanda Magalhães / Natália Botica

1479 Cerâmicas e Vidros da Antiguidade Tardia do Edifício sob a Igreja do Bom Jesus (Vila Nova de Gaia) Joaquim Filipe Ramos

1493 Novos contributos para a topografia histórica de Mértola no período romano e na Antiguidade Tardia Virgílio Lopes

\section{8. Época Medieval}

1511 Cerâmicas islâmicas no Garb setentrional "português": algumas evidências e incógnitas Constança dos Santos / Helena Catarino / Susana Gómez / Maria José Gonçalves / Isabel Inácio / Gonçalo Lopes / Jacinta Bugalhão / Sandra Cavaco / Jaquelina Covaneiro / Isabel Cristina Fernandes / Ana Sofia Gomes 
1525 Contributo para o conhecimento da cosmética islâmica, em Silves, durante a Idade Média Rosa Varela Gomes

1537 Yábura e o seu território - uma análise histórico-arqueológica de Évora entre os séculos VIII-XII José Rui Santos

1547 A encosta sul do Castelo de Palmela - resultados preliminares da escavação arqueológica Luís Filipe Pereira / Michelle Teixeira Santos

1559 A igreja de São Lourenço (Mouraria, Lisboa): um conjunto de silos e de cerâmica medieval islâmica

Andreia Filipa Moreira Rodrigues

1571 O registo material de movimentações populacionais no Médio Tejo, durante os séculos XII-XIII. Dois casos de "sunken featured buildings", nos concelhos de Cartaxo e Torres Novas Marco Liberato / Helena Santos / Nuno Santos

1585 O nordeste transmontano nos alvores da Idade média. Notas para reflexão Ana Maria da Costa Oliveira

1601 Sepulturas escavadas na rocha do Norte de Portugal e do Vale do Douro: primeiros resultados do Projecto SER-NPVD

Mário Jorge Barroca / César Guedes / Andreia Arezes / Ana Maria Oliveira

1619 "Portucalem Castrum Novum" entre o Mediterrâneo e o Atlântico: o estudo dos materiais cerâmicos alto-medievais do arqueossítio da rua de D. Hugo, nํ. 5 (Porto) João Luís Veloso

1627 A Alta Idade Média na fronteira de Lafões: notas preliminares sobre a Arqueologia no Concelho de Vouzela

Manuel Luís Real / Catarina Tente

1641 Um conjunto cerâmico medieval fora de portas: um breve testemunho aveirense Susana Temudo

${ }_{1651}$ Os Lóios do Porto: uma perspetiva integrada no panorama funerário da Baixa Idade Média à Época Moderna em meios urbanos em Portugal

Ana Lema Seabra

1659 O Caminho Português Interior de Santiago como eixo viário na Idade Média Pedro Azevedo

1665 Morfologia Urbana: Um exercício em torno do Castelo de Ourém André Donas-Botto / Jaqueline Pereira

1677 Intervenção arqueológica na Rua Marquês de Pombal/Largo do Espírito Santo (Bucelas, Loures)

Florbela Estêvão / Nathalie Antunes-Ferreira / Dário Ramos Neves / Inês Lisboa

1691 O Cemitério Medieval do Poço do Borratém e a espacialidade funerária na cidade de Lisboa Inês Belém / Vanessa Filipe / Vasco Noronha Vieira / Sónia Ferro / Rodrigo Banha da Silva

1705 Um Espaço Funerário Conventual do séc. XV em Lisboa: o caso do Convento de São Domingos da Cidade Sérgio Pedroso / Sílvia Casimiro / Rodrigo Banha da Silva / Francisca Alves Cardoso

\section{9. Época Moderna e Contemporânea}

1721 Arqueologia Moderna em Portugal: algumas reflexões críticas em torno da quantificação de conjuntos cerâmicos e suas inferências históricas e antropológicas Rodrigo Banha da Silva / André Bargão / Sara da Cruz Ferreira

1733 Faianças de dois contextos entre os finais do século XVI e XVIII do Palácio dos Condes de Penafiel, Lisboa

Martim Lopes / Tomás Mesquita 
1747 Um perfil de consumo do século XVIII na foz do Tejo: O caso do Mercado da Ribeira, Lisboa Sara da Cruz Ferreira / Rodrigo Banha da Silva / André Bargão

1761 Os Cachimbos dos Séculos XVII e XVIII do Palácio Mesquitela e Convento dos Inglesinhos (Lisboa)

Inês Simão / Marina Pinto / João Pimenta / Sara da Cruz Ferreira / André Bargão / Rodrigo Banha da Silva

1775 "Tomar os fumos da erua que chamão em Portugal erua sancta». Estudo de Cachimbos provenientes da Rua do Terreiro do Trigo, Lisboa

Miguel Martins de Sousa / José Pedro Henriques / Vanessa Galiza Filipe

1787 Cachimbos de Barro Caulínitico da Sé da Cidade Velha (República de Cabo Verde)

Rodrigo Banha da Silva / João Pimenta / Clementino Amaro

1801 Algumas considerações sobre espólio não cerâmico recuperado no Largo de Jesus (Lisboa) Carlos Boavida

1815 Adereços de vidro, dos séculos XVI-XVIII, procedentes do antigo Convento de Santana de Lisboa (anéis, braceletes e contas)

Joana Gonçalves / Rosa Varela Gomes / Mário Varela Gomes

1837 Da ostentação, luxo e poder à simplicidade do uso quotidiano: arqueologia e simbologia de joias e adornos da Idade Moderna Portuguesa Jéssica Iglésias

1849 Os amuletos em Portugal - dos objetos às superstições: o coral vermelho Alexandra Vieira

1865 Cerâmicas de Vila Franca de Xira nos séculos XV e XVI Eva Pires

1879 «Não passa por teu o que me pertence». Marcas de individualização associadas a faianças do Convento de Nossa Senhora de Aracoeli, Alcácer do Sal Catarina Parreira / Íris Fragoso / Miguel Martins de Sousa

1891 Cerâmica de Leiria: alguns focos de produção

Jaqueline Pereira / André Donas-Botto

1901 Os Fornos na Rua da Biquinha, em Óbidos Hugo Silva / Filipe Oliveira

1909 A casa de Pêro Fernandes, contador dos contos de D. Manuel I: o sítio arqueológico da Silha do Alferes, Seixal (século XVI) Mariana Nunes Ferreira

1921 O Alto da Vigia (Sintra) e a vigilância e defesa da costa Alexandre Gonçalves / Sandra Santos

1937 O contexto da torre sineira da Igreja de Santa Maria de Loures Paulo Calaveira / Martim Lopes

1949 A Necrópole do Hospital Militar do Castelo de São Jorge e as práticas funerárias na Lisboa de Época Moderna Susana Henriques / Liliana Matias de Carvalho / Ana Amarante / Sofia N. Wasterlain

1963 SAND - Sarilhos Grandes Entre dois Mundos: o adro da Igreja e a Paleobiologia dos ossos humanos recuperados

Paula Alves Pereira / Roger Lee Jesus / Bruno M. Magalhães

1975 Expansão urbana da vila de Cascais no século XVII e XVIII: a intervenção arqueológica na Rua da Vitória no 15 a 17

Tiago Pereira / Vanessa Filipe

1987 Novos dados para o conhecimento do Urbanismo de Faro em época Moderna Ana Rosa 
1995 Um exemplo de Arqueologia Urbana em Alcoutim: o Antigo Edifício dos CTT Marco Fernandes / Marta Dias / Alexandra Gradim / Virgílio Lopes / Susana Gómez Martínez

2007 Palácio dos Ferrazes (Rua das Flores/Rua da Vitória, Porto): a cocheira de Domingos Oliveira Maia

Francisco Raimundo

2021 As muitas vidas de um edifício urbano: História, Arqueologia e Antropologia no antigo Recreatório Paroquial de Penafiel Helena Bernardo / Jorge Sampaio / Marta Borges

2035 O convento de Nossa Senhora da Esperança de Ponta Delgada: o contributo da arqueologia para o conhecimento de um monumento identitário João Gonçalves Araújo / N’Zinga Oliveira

2047 Arqueologia na ilha do Corvo... em busca da capela de Nossa Senhora do Rosário Tânia Manuel Casimiro / José Luís Neto / Luís Borges / Pedro Parreira

2059 Perdidos à vista da Costa. Trabalhos arqueológicos subaquáticos na Barra do Tejo Jorge Freire / José Bettencourt / Augusto Salgado

2071 Arqueologia marítima em Cabo Verde: enquadramento e primeiros resultados do projecto CONCHA

José Bettencourt / Adilson Dias / Carlos Lima / Christelle Chouzenoux / Cristóvão Fonseca / Dúnia Pereira / Gonçalo Lopes / Inês Coelho / Jaylson Monteiro / José Lima / Maria Eugénia Alves / Patrícia Carvalho / Tiago Silva

2085 Trabalhos arqueológicos na Cidade Velha (Ribeira Grande de Santiago, Cabo Verde): reflexões sobre um projecto de investigação e divulgação patrimonial André Teixeira / Jaylson Monteiro / Mariana Mateus / Nireide Tavares / Cristovão Fonseca / Gonçalo C. Lopes / Joana Bento Torres / Dúnia Pereira / André Bargão / Aurélie Mayer / Bruno Zélie / Carlos Lima / Christelle Chouzenoux / Inês Henriques / Inês Pinto Coelho / José Lima / Patrícia Carvalho / Tiago Silva

2103 A antiga fortificação de Quelba / Khor Kalba (E.A.U.). Resultados de quatro campanhas de escavações, problemáticas e perspectivas futuras Rui Carita / Rosa Varela Gomes / Mário Varela Gomes / Kamyar Kamyad

2123 Colónias para homens novos: arqueologia da colonização agrária fascista no noroeste ibérico Xurxo Ayán Vila / José Mạ . Señorán Martín 


\title{
ARQUEOLOGIA E ARQUEÓLOGOS NO NORTE DE PORTUGAL
}

\author{
Jacinta Bugalhão'
}

\begin{abstract}
RESUMO
Este trabalho pretende apresentar dados quantitativos sobre a Arqueologia no Norte de Portugal entre 1970 e início do século XX. São analisados o ensino da Arqueologia, os arqueólogos, as instituições com actividade em Arqueologia e a actividade arqueológica, procurando identificar convergências e divergências, relativamente ao todo nacional. São abordados os estabelecimentos de ensino superior da região e a sua oferta formativa. São apresentadas as distribuições por sexo, idade, habilitação, forma de exercício da actividade, tipo de vínculo laboral e enquadramento institucional dos arqueólogos naturais da região Norte. Sobre a actividade arqueológica são abordadas a categoria (investigação, valorização, preventiva e de emergência), tipologia e enquadramento institucional e também a Arqueologia urbana e a desenvolvida em meio subaquático ou húmido.

Palavras-chave: Arqueologia portuguesa, História da Arqueologia, Região Norte, Actividade arqueológica, Profissão de arqueólogo.
\end{abstract}

\begin{abstract}
This paper intends to present quantitative data on Archeology in the North of Portugal between 1970 and the beginning of the $2 \mathrm{O}^{\text {th }}$ century. Archeology teaching, archaeologists, institutions with labour in Archeology and archaeological activity are analyzed, seeking to identify convergences and divergences, in relation to the national reality. Higher education establishments in the region and their training offer are covered. The distributions by sex, age, qualification, form of exercise of the activity, type of employment relationship and institutional framework of northern archaeologists are presented. On the archaeological activity, the category (research, valorisation, preventive and emergency), typology and institutional framework and also urban archeology and the one developed in underwater or humid environments are addressed.

Keywords: Portuguese archeology, History of Archeology, North region, Archaeological activity, Profession of archaeologist.
\end{abstract}

\section{1. ÂMBITO}

Neste trabalho apresentam-se os dados relativos à região Norte recolhidos no âmbito do projeto de doutoramento (em fase de conclusão) desenvolvido pela signatária desde 2012, na Faculdade de Letras da Universidade de Lisboa (com a UNIARQ e a DGPC como entidades de acolhimento), sob orientação de Carlos Fabião, subordinado ao tema "A Arqueologia em Portugal, entre o final do século XX e o início do século XXI". A sua principal fonte de informa- ção é o Endovélico, sistema de informação e gestão arqueológica, gerido pela DGPC.

No presente trabalho considera-se a região Norte conforme ela está definida no Decreto-Lei n.. 68/2008 de 14 de Abril que delimita as unidades territoriais para efeitos de organização territorial e estatística (NUTS) ${ }^{2}$ (Figura 1). O período em estudo corresponde aos 45 anos compreendidos entre 1970 e 2014, e foi decomposto em quinquénios, para análise evolutiva.

$\mathrm{Na}$ análise de dados quantitativos, os valores apre-

1. DGPC; UNIARQ/Faculdade de Letras da Universidade de Lisboa; Centro de Estudos de Arqueologia, Artes e Ciências do Património; jacintabugalhao@gmail.com

2. A região Norte inclui as sub-regiões Minho-Lima, Cávado, Ave, Grande Porto, Tâmega, Entre Douro e Vouga, Douro e Alto Trás-os-Montes, compreendendo 86 conselhos. A delimitação das NUTS vem sofrendo actualizações, em 2009, 2013 e 2015, mas a configuração da região (NUTS II) Norte mantém-se inalterada. 
sentados referem-se aos que foi possível apurar nos universos em análise (arqueólogos, instituições, trabalhos arqueológicos, projectos, etc).

\section{ENSINO SUPERIOR DA ARQUEOLOGIA NO NORTE DE PORTUGAL}

O ensino da Arqueologia nas universidades portuguesas começou disperso em disciplinas clássicas como filologia, história de arte antiga, epigrafia, numismática. No final do século XIX, com o desenvolvimento dos estudos pré-históricos, alguns conteúdos arqueológicos foram marcando presença no ensino das ciências naturais, nomeadamente na área científica da Geologia. A partir de 1911, Mendes Correia ensinou Antropologia na Faculdade de Ciências da Universidade do Porto, na qual chegou a catedrático (Fabião, 1999, p. 120). O mesmo arqueólogo ensinou a Arqueologia na Faculdade de Letras da Universidade do Porto (Fabião, 2011, p. 170), entre 1919 e 1922 (Centeno, Soeiro e Sanches, 2013, p. 33). Nos anos 50 do século XX, D. Domingos de Pinho Brandão ensinou Arqueologia no Seminário Maior do Porto (Centeno, Soeiro e Sanches, 2013, p. 36). Na reforma das leis orgânicas das Faculdades de Letras de 1957 é considerada a licenciatura em História (que integrava as disciplinas de Pré-História e de Arqueologia) e instituído o doutoramento em Arqueologia. Em 1961, após a restauração da Faculdade de Letras do Porto (Centeno, Soeiro e Sanches, 2013, p. 35) são aí disponibilizados os cursos de licenciatura em História e de doutoramento em Arqueologia (Centeno, Soeiro e Sanches, 2013, p. 36). A partir de 1968, as disciplinas de Pré-História e Arqueologia ficam sob a responsabilidade de Carlos Alberto Ferreira de Almeida (Centeno, Soeiro e Sanches, 2013, p. 38).

A seguir ao 25 de Abril, em 1975, operaram-se reformas dos cursos de História, comtemplando a criação da "pré-especialização" em Arqueologia, nas três universidades clássicas (Arnaud, 2013, p. 77; Centeno, Soeiro e Sanches, 2013, p. 38), assumindo, por vezes, configuração mais especializada, como foi o caso "pré-especialização" em Pré-História ministrada na Faculdade de Letras do Porto. Nos últimos anos da década de 70 do século XX, a Universidade de Braga cria áreas de investigação em Arqueologia (Lemos, 1987, p. 8). Na Faculdade de Letras da Universidade do Porto, onde leccionavam Arqueologia seis docentes (Centeno, Soeiro e Sanches, 2013, p. 38), são reforçados os conteúdos relativos à Pré-
-História e, em 1978, é criada a variante História de Arte e Arqueologia (Jorge, 2003, p. 1454; Centeno, Soeiro e Sanches, 2013, p. 43).

Em 1980 começa a funcionar a variante Arqueologia da licenciatura em História na Faculdade de Letras do Porto (Jorge e Marques, 1992, p. 36; Jorge, 2003, p. 1454; Centeno, Soeiro e Sanches, 2013, p. 43) e, mais tarde, em 1998, na Universidade do Minho (Meireles, 2006, p. 117). A partir de 1990 a Escola Profissional de Arqueologia do Freixo, Marco de Canaveses oferece formação profissional de nível secundário em Arqueologia (Dias, 1998, p. 38). A Faculdade de Letras da Universidade do Porto teve um papel muito relevante no processo de autonomização do ensino universitário da Arqueologia. Após a já referida variante, criou, em 1989, o primeiro curso de Mestrado em Arqueologia a funcionar em Portugal (Jorge e Marques, 1992, p. 36; Jorge, 2003, p. 1454; Centeno, Soeiro e Sanches, 2013, p. 43). Em 1996, foi criado na mesma faculdade o Mestrado em Arqueologia Pré-Histórica.

$\mathrm{Na}$ Universidade do Minho, o ensino na Arqueologia iniciou-se no âmbito da licenciatura em História e Ciências Sociais (Jorge e Marques, 1992, p. 36). Refiram-se ainda os estabelecimentos de ensino superior com investigadores e áreas de investigação em Arqueologia, na Universidade de Trás-os-Montes e Alto Douro e na Universidade Portucalense Infante D. Henrique (Jorge e Marques, 1992, p. 36). $\mathrm{Na}$ Faculdade de Letras da Universidade do Porto, é finalmente instituída a primeira licenciatura em Arqueologia em 1999 (Jorge, 2003, p. 1454; Soeiro, 2006, p. 118) e também o curso de Doutoramento em Arqueologia (Centeno, Soeiro e Sanches, 2013, p. 44). Na Universidade do Minho, é criada em 2003 a Licenciatura em Arqueologia e o doutoramento em Arqueologia.

Entretanto, decorre o processo de Bolonha em Portugal (Raposo, 2006). Na Faculdade de Letras da Universidade do Porto, em 2007, são adaptados os cursos de mestrado e doutoramento (2.. e $3 .^{\circ}$ ciclo) em Arqueologia. Na Universidade do Minho, sucedem-se entre 2007 e 2012 adaptações e alterações do mestrado em Arqueologia. A Universidade de Trás-os-Montes e Alto Douro cria, em 2007, o doutoramento em Quaternário Materiais e Culturas e, em 2005, em colaboração com o Instituto Politécnico de Tomar, o mestrado em Arqueologia Pré-Histórica e Arte Rupestre. Ao nível dos estabelecimentos privados, registaram-se os mestrados em 
de Arqueologia, na Universidade Fernando Pessoa, em 2007 e na Universidade Portucalense Infante D. Henrique, em 2009.

Em estudo anterior, foram analisados os dados quantitativos e evolutivos disponíveis para a obtenção de grau académico superior - licenciaturas, mestrados e doutoramento - na área científica da Arqueologia (Bugalhão, 2016; Bugalhão, 2017, p. 126-128), em Portugal, entre 1970 e $2014^{3}$.

Em Portugal, entre 1978 e 2014, terão concluído licenciatura/1.. ciclo de Bolonha na área científica da Arqueologia cerca de 2.500 alunos ${ }^{4}$ (Bugalhão, 2016), dos quais cerca de $34 \%$ diplomaram-se em estabelecimentos de ensino da região Norte $(70 \%$ na Faculdade de Letras do Porto e $30 \%$ na Universidade do Minho).

Relativamente ao mestrado/2..$^{\circ}$ ciclo de Bolonha, entre 1983 e 2014, registaram-se 724 graduados (em Arqueologia, e outras áreas científicas como a História, Antropologia, Arqueologia, Geologia, Geografia, Física, Química, Sistemas de Informação e Informática, Filosofia, Literatura, Arquitectura e Artes, Conservação e Restauro, Museologia, Património, Cultura e Turismo) com dissertação sobre temática arqueológica (Bugalhão, 2016). Na região Norte foram obtidos 242 graus de mestrado/2.. ciclo de Bolonha, entre 1993 e 2014 (33\% do total). Destes, $57 \%$ foram obtidos na Faculdade de Letras da universidade do Porto, $22 \%$ na Universidade do Minho, $17 \%$ na Universidade de Trás-os-Montes e Alto Douro (por vezes em parceria com o Instituto Politécnico de Tomar) e $4 \%$ em outros estabele-

3. Relativamente às licenciaturas, recorreu-se aos dados estatísticos da DGEEC (disponíveis apenas desde 1993), relativos aos graus obtidos em estabelecimentos de ensino superior portugueses. Relativamente aos mestrados e doutoramentos, consideraram-se considerados todos os diplomados em Arqueologia (ou outras áreas científicas mas com dissertação na temática arqueológica), entre 1970 e 2014, em estabelecimentos de ensino superior portugueses e estrangeiros, que incidiram sobre contextos arqueológicos portugueses (incluindo Arqueologia das antigas colónias portuguesas, na perspectiva da História da Arqueologia e contextos arqueológicos portugueses fora do território português) ou sem delimitação geográfica específica.

4. Estima-se em cerca de 50 o número de licenciados em História, com "pré-especialização" em Arqueologia a nível nacional. Entre 1985 e 1992, estimam-se em 250 os licenciados em História, variante Arqueologia. A partir dos dados disponibilizados pela DGEEC sabe-se que, entre $1993 \mathrm{e}$ 2014, se registam 1.956 licenciados em Arqueologia. cimentos de ensino superior (como a Faculdade de Ciências da Universidade do Porto, a Universidade Católica do Porto, a Universidade Fernando Pessoa e a Universidade Portucalense).

Quanto ao grau de doutoramento/3. ${ }^{\circ}$ ciclo de Bolonha, entre 1974 e 2014, registaram-se 195 diplomados (em Arqueologia, nas outras áreas científicas já referidas para mestrado/2.. ciclo) com dissertação sobre temática arqueológica, em estabelecimentos de ensino superior portugueses e estrangeiros (incidindo sobre contextos arqueológicos portugueses) (Bugalhão, 2016), dos quais, 24\% foram obtidos em universidades da região. Distribuem-se entre a Faculdade de Letras da Universidade do Porto (50\%), Universidade do Minho (35\%) e a Universidade de Trás-os-Montes e Alto Douro (15\%).

Em termos evolutivos, analisados os graus conferidos pelos estabelecimentos de ensino superior da região Norte pode observar-se uma tendência crescente no número de licenciados, interrompida apenas no último quinquénio (provavelmente devido à diminuição do número de alunos no ensino superior em consequência da crise económica e financeira), idêntica à verificada a nível nacional (Gráfico 1). Nos mestrados regista-se um primeiro momento de crescimento no quinquénio de 1995-1999, relacionado com a criação do mestrado de Arqueologia na Faculdade de Letras do Porto, seguido de dez anos de alguma estabilização (quando no resto do país este valor se mantém crescente) e dos últimos dez anos em estudo de forte aumento do número de diplomados (Gráfico 1). O número de doutorados na região é bastante modesto até 2004, revelando forte crescimentos nos dez anos seguintes, numa evolução semelhante ao todo nacional (Jorge, 1986, p. 2; Jorge e Marques, 1992, p. 36; Jorge e Jorge, 1996, p. 165; Lemos, 2003, p. 49; Silva, 2003, p. 68; Lemos, 2007, p. 107; Bugalhão, 2017, p. 23; 30) (Gráfico 1). $\mathrm{O}$ ensino superior da Arqueologia na região Norte iniciou-se no início do século XX na Universidade do Porto, onde em 1957, foi instituído o grau de doutor em Arqueologia e História de Arte. Entre meados dos anos 70 e os anos 9o, verificou-se uma tendência de especialização no ensino superior da Arqueologia e o número de estabelecimentos de ensino superior envolvido neste aumenta e dispersa-se mais no território. A partir de 1995, aumenta o número de mestrados e de 2005, de doutoramentos, numa tendência muito acentuada pela implementação do modelo de Bolonha no ensino superior por- 
tuguês e pela alteração do regime jurídico de enquadramento da actividade arqueológica. A evolução da formação superior em Arqueologia na região Norte contribuiu para a alteração muito significativa do nível habilitacional dos arqueólogos em Portugal, que evoluiu da quase ausência ou indistinção, para uma realidade de elevada, cumulativa e especializada qualificação académica e científica.

\section{ARQUEÓLOGOS DO NORTE DO PAÍS}

Os dados aqui apresentados foram recolhidos no referido projecto de doutoramento, no qual se identificaram 2.080 arqueólogos com actividade em Portugal entre 1970 e 2014, dos quais 1.837 com nacionalidade portuguesa. Os valores apurados revelaram que neste período trabalharam em Portugal 309 arqueólogos naturais da região Norte (das mais populosas e urbanizadas do país), ou seja $26 \%$ do total de arqueólogos com nacionalidade portuguesa (Bugalhão, 2017, p. 23; 28-29). É importante sublinhar que os dados aqui tratados se referem à região de naturalidade dos arqueólogos e não à região de actividade dos arqueólogos.

A naturalidade dos arqueólogos foi confrontada com os valores globais de naturalidade da população nascida em Portugal ${ }^{5}$. A comparação destes valores, e com as cautelas que se impõem devidas à natureza muito diferente dos dados, permite propor que os arqueólogos naturais da região Norte ( $28 \%$ do total de portugueses se excluídos os nascidos fora do país) representam um peso relativo consideravelmente inferior ao da população nascida naquela região, $40 \%$ ). Foi também analisada a evolução do peso relativo dos arqueólogos em actividade entre 1970 e 2014 nascidos na região Norte, concluindo-se que estes ganham peso relativo ao longo do período em estudo, representando inicialmente $19 \%$ do total e, no último quinquénio, $26 \%$ do total (Gráfico 2). $\mathrm{Na}$ distribuição por sexo dos arqueólogos nascidos na região Norte, registam-se $63 \%$ de homens e $37 \%$ de mulheres. Aliás, a região Norte, regista a única espe-

5. Utilizaram-se como referência os dados disponibilizados pela PORDATA/INE (estatísticas de Nados-Vivos) relativos à taxa bruta de natalidade no país (portugueses nascidos fora do país não são considerados) em 1981 (inclui todos os nascimentos e não apenas os de nacionais portugueses), sendo estes comparados com os valores dos arqueólogos nascidos entre 1980 e 1989, em actividade em Portugal entre 1970 e 2014. cificidade regional divergente da situação de paridade verificada a nível nacional (Bugalhão, 2017, p. 22), revelando uma sub-representação do sexo feminino. Refira-se ainda que entre os arqueólogos portugueses do sexo masculino em actividade em Portugal no período em estudo, $30 \%$ nasceram no Norte; do sexo feminino, apenas $21 \%$ nasceram nesta região.

Quando analisada a evolução quinquenal da distribuição por naturalidade de homens e mulheres, verifica-se que entre os naturais da região Norte há sempre mais homens que mulheres, embora a diferença se vá atenuando (Gráfico 3). Entre os naturais do Norte do país, no período em estudo, a profissão de arqueólogo não alcançou (ainda) a paridade de género, já alcançada a nível nacional (Bugalhão, no prelo).

A análise evolutiva da estrutura etária dos arqueólogos nascidos no Norte do país foi efectuada através do apuramento da sua média etária ${ }^{6}$ em cada quinquénio. À semelhança do que ocorre a nível nacional (Bugalhão, 2017, p. 23 e 29), este valor revela um rejuvenescimento progressivo dos arqueólogos nascidos na região, em actividade entre 1970 e 2009, seguida de uma ligeira subida da média etária no último quinquénio em análise. Comparativamente com a realidade nacional, até 1984 os arqueólogos nascidos no Norte são tendencialmente mais velhos; entre 1985 e 2004, revelam média etária idêntica à nacional; e entre 2005 e 2014, são mais jovens (Gráfico 4 ).

Foram também analisadas as habilitações académicas dos arqueólogos com naturalidade nortenha, apurando-se que $98 \%$ possuem licenciatura/1..${ }^{\circ}$ ciclo de Bolonha, $39 \%$ possuem mestrado/2.. ciclo, $9 \%$ possuem doutoramento/ $3 .$. ciclo e $2 \%$ possuem outras habilitações "não secundárias"7 (valor particularmente elevado). Comparativamente à realidade nacional, os nortenhos registam um valor relativo superior de mestres/2. ${ }^{\circ}$ ciclo (eventual-

6. A média etária dos arqueólogos em actividade no quinquénio foi calculada a partir da idade de cada arqueólogo completada no terceiro ano do mesmo.

7. Na categoria "outras habilitações académicas não secundárias” integraram-se as qualificações académicas subsequentes ao ensino secundário, não obtidas em estabelecimento de ensino superior. Enquadram-se nesta categoria os estudos religiosos, militares e do chamado "magistério primário", outros cursos conferentes de grau académico "médio" ou ainda curso de ensino informal (por exemplo o curso de conservador de museu). 
mente relacionado com a criação e funcionamento do primeiro mestrado em Arqueologia em Portugal, na Faculdade de Letras do Porto, no final dos anos 8 o do século $\mathrm{XX}$ ) e um valor relativo inferior de doutorados $/ 3$. ․ ciclo de Bolonha. Ao contrário do que se passa noutras regiões (Bugalhão, 2017, p. 23), não se regista nenhum arqueólogo natural da região Norte, que tenha permanecido sem habilitação académica superior durante todo o período em estudo. À semelhança do ocorrido a nível nacional, os arqueólogos nascidos na região Norte tornam-se progressivamente mais qualificados ao longo do período em estudo (Gráfico 5).

Relativamente à forma de exercício da actividade, $13 \%$ dos arqueólogos nascidos na região Norte foram arqueólogos amadores (especialmente nos primeiros quinze anos em estudo), tratando-se, na sua maioria, de professores do ensino básico e secundário, profissionais de museus e bibliotecas e membros do clero. Os arqueólogos profissionais representam $90 \%$ do total e para estes foi analisado o tipo de vínculo, relação ou situação laboral. Entre os arqueólogos profissionais naturais da região Norte, $66 \%$ foram trabalhadores independentes, $33 \%$ trabalhadores dependentes, 10\% empresários e 5\% bolseiros/investigadores (note-se que um arqueólogo regista frequentemente no seu currículo vários tipos de vínculo, relação ou situação laboral). Comparativamente com os valores nacionais (Bugalhão, 2017, p. 24-25 e 31), entre os naturais do Norte regista-se uma incidência superior de trabalho independente e de empresários; e uma incidência inferior de trabalho dependente e de bolseiros/investigadores. Até aos anos 80 do século XX, os arqueólogos em actividade em Portugal eram trabalhadores dependentes ou amadores. Na evolução quinquenal (apenas a partir de 1990, quando esta distinção se justifica), observa-se naturalmente um crescimento do trabalho independente (que surge com valores assinaláveis de forma precoce nesta região), mas também o surgimento e consolidação dos empresários, bem como dos bolseiros/investigadores (Gráfico 6). $\mathrm{O}$ enquadramento institucional do trabalho dos arqueólogos em Portugal caracteriza-se por uma forte instabilidade, volatilidade e versatilidade. Sublinha-se por isso que um arqueólogo, no período em estudo e em cada quinquénio, pode trabalhar apenas para ou numa instituição ou para ou em várias. Salienta-se também que o trabalho de arqueólogos enquadrado por empresas de arqueologia, outro tipo de empresas ou sem enquadramento institucional se implanta e consolida apenas a partir dos anos 90 do século XX. Entre os arqueólogos nascidos na região Norte, $65 \%$ trabalharam sem qualquer enquadramento institucional, 59\% trabalharam em empresas de arqueologia, 30\% na administração pública local, $27 \%$ em universidades ou unidade de investigação portuguesas, $18 \%$ em outro tipo de empresas, 12\% na administração pública central, 10\% em associação, e um número residual (1) trabalhou para universidade ou unidade de investigação estrangeira (Gráfico 7). Comparativamente com a realidade nacional, os arqueólogos nascidos no Norte têm o seu trabalho mais frequentemente enquadrado pela administração pública local, por universidades ou unidade de investigação portuguesas e por empresas, de arqueologia e outras. Pelo contrário, os arqueólogos nascidos no Norte têm o seu trabalho mais raramente enquadrado pela administração pública central, associações e universidades ou unidades de investigação estrangeiras. Os arqueólogos nortenhos trabalham mais frequentemente sem qualquer enquadramento institucional, situação fortemente relacionada com o trabalho em regime liberal ou independente.

\section{INSTITUIÇÕES COM ACTIVIDADE EM ARQUEOLOGIA DO NORTE DO PAÍS}

Foram analisadas as instituições com actividade em Arqueologia entre 1970 e 2014, sedeadas na região Norte de Portugal, tendo-se contabilizado um total de 200 entidades ( $22 \%$ do total nacional), entre as quais se incluem 42 museus de Arqueologia ou com colecções de Arqueologia ( $27 \%$ do total nacional). Estas instituições enquadram o trabalho dos arqueólogos mas desempenham também outras importantes funções (frequentemente em acumulação), como a museológica, a gestão de espólios e colecções arqueológicas, a tutelar, o apoio à investigação, a representação académica, profissional e sindical, a edição científica, etc. Foi analisada a distribuição por tipo das instituições com actividade em Arqueologia sedeadas na região Norte. O grupo maioritário é constituído por organismos da administração pública local ${ }^{8}$ (39\%), seguindo-se as asso-

8. A categoria “Administração Pública Local” integra maioritariamente municípios, mas também outro tipo de organismos autárquicos. 
ciações (20\%), as empresas fora do sector arqueológico $^{9}(14 \%)$, as empresas de arqueologia (13\%), as universidades e unidades de investigação portuguesas (6\%), a administração pública central (5\%) e, por fim, os outros tipos de instituição ${ }^{10}(3 \%)$ (Gráfico 8). Os organismos da administração pública local são as instituições com actividade em Arqueologia mais numerosas na região Norte, realidade possivelmente potenciada pela a elevada concentração de municípios nesta região ( $31 \%$ dos localizados no território continental). Entre 1980 e a actualidade, os municípios intensificaram determinantemente a sua actividade nas várias frentes e tarefas, consolidando-se como as principais instituições da Arqueologia nacional (Jorge, 1986, p. 2; Lemos, 1987, p. 10; Real, 1993, p. 25-26; Almeida, 2007a, p. 132). As associações são o segundo tipo de instituição mais representado, espelhando a sua importância na Arqueologia da região. Entre 2000 e 2014, as empresas de arqueologia são principais entidades enquadrantes da actividade arqueológica (Lago, 2003, p. 103; Bugalhão, 2011, p. 27) e principais as entidades de enquadramento do trabalho de arqueólogos (principalmente dos mais jovens), como contratantes e/ou empregadoras (Almeida, 2007, p. 130; Bugalhão, 2011, p. 35-36; Bugalhão, 2017, p. 25). No Norte, encontra-se sedeado um número razoável de universidades ou unidades de investigação, ao contrário do que sucede nas regiões mais periféricas, menos desenvolvidas e menos povoadas do país.

Relativamente à evolução temporal, verifica-se uma tendência de crescimento linear ao longo de todo o período em análise, mais intensa entre 1995 e 2004, relacionada com a progressiva estruturação, organização e institucionalização da Arqueologia nacional. Até aos anos 80 do século XX, a actividade arqueológica desenvolve-se de forma amadora ou proto-profissional, baseada frequentemente na ini-

\footnotetext{
9. Na categoria "Empresa-Outras" consideraram-se as empresas não sendo exclusivamente prestadoras de serviços de arqueologia contratam e enquadram actividade arqueológica, nomeadamente, empresas com actividade na avaliação de impacte ambiental, empreiteiros, promotores imobiliários, empresas gestoras de redes de infra-estruturas básicas, etc, e também as editoras de bibliografia arqueológica (o que contribui para a sua elevada representação quantitativa).

10. Na categoria "Outros" foram incluídos os tipos com uma presença muito residual no universo em análise, por exemplo, escolas de ensino básico e secundário, fundações e organismos eclesiásticos.
}

ciativa individual e sem suporte institucional. Nesta fase, menos institucionalizada, verifica-se uma intervenção mais intensa de organismos públicos e associações. Numa segunda fase, mais institucionalizada, assumem prevalência as entidades privadas (Gráfico 9).

\section{ACTIVIDADE ARQUEOLÓGICA NA REGIÃO NORTE}

Os trabalhos arqueológicos realizados na região Norte de Portugal entre 1970 e 2014 correspondem a $32 \%$ dos realizados em Portugal continental. Em termos absolutos, o número de trabalhos arqueológicos desenvolvidos no Norte demonstra uma tendência de crescimento entre 1970 e 2009, seguida de uma retracção no quinquénio de 2010-2014. $\mathrm{Na}$ evolução quinquenal, a região Norte representa entre 1o e $42 \%$ do total nacional. Entre 1975 e 1989 , a maioria dos trabalhos arqueológico decorrem no Norte (entre 27 e $42 \%$ ), situação que se repete entre 2000 e 2004 (26\%). Os projectos de enquadramento da actividade arqueológica realizado no Norte representam $29 \%$ do total nacional. Em termos evolutivos e em correspondência com o verificado para os trabalhos arqueológicos, observa-se que a região Norte regista o número mais elevado de projectos entre 1975 e 1984 (30 e $38 \%$ do total) e entre 1995 e 2014 (entre 28 e 30\%) (Gráfico 10).

No que se refere à categoria ${ }^{11}$ dos trabalhos arqueológicos, na região Norte decorreu a maioria dos trabalhos de investigação e preventivos realizados em Portugal no período em estudo. Na perspectiva evolutiva, regista-se duas fases distintas. Até 1999, a maioria dos trabalhos arqueológicos enquadram-se na categoria A - Investigação. A partir de 2000 e de forma progressivamente mais intensa, a maioria dos trabalhos arqueológicos enquadram-se na categoria C - Preventiva (Gráfico 11).

A Arqueologia de investigação (categoria A) desenvolvida na região Norte representa $27 \%$ do total. Procurou-se caracterizar o objecto dos projectos de investigação, nomeadamente, o (ou os) período

\footnotetext{
11. Conforme o n. ${ }^{1} 1$ do artigo $3 .{ }^{\circ}$ do Regulamento de Trabalhos Arqueológicos (Decreto-Lei n.ํㅜㄹo/99 de 15 de Julho) e o artigo 3. - do Regulamento de Trabalhos Arqueológicos (Decreto-Lei n.. ${ }^{\circ}$ 164/2014 de 4 de novembro).
} 
cronológico $^{12}$ sobre o qual incidem. A investigação em contextos proto-históricos é especialmente relevante no Norte e pré-história recente alcança representação relativa significativa (Gráfico 12).

Os trabalhos de valorização (categoria B) no Norte do país representam $29 \%$ dos realizados a nível nacional. Registam tendência crescente até 2009 e, comparativamente com o todo nacional, assumem maior preponderância entre 1975 e 1984 e entre 2005 e 2009 (Gráfico 11). Em 2016, 26\% dos sítios arqueológicos valorizados situavam-se na região Norte (Raposo, 2016, p. 72-73).

Os trabalhos arqueológicos preventivos (categoria C) realizados no Norte representam $25 \%$ do total nacional, incluindo: trabalhos realizados no âmbito de processos de licenciamento e obras (56\%); trabalhos realizados no âmbito de processos de avaliação de impacte ambiental (39\%); trabalhos realizados no âmbito de projectos de carta arqueológica e ordenamento e gestão do território (3\%); e trabalhos realizados no âmbito de projectos de intervenção e/ ou valorização de Património arquitectónico (3\%). Os trabalhos de emergência (categoria D) realizados na região Norte representam 20\% do total nacional e atingiram representação quantitativa máxima nos anos 80 do século XX (Gráfico 11).

Relativamente ao tipo de trabalho, as intervenções desenvolvidas na região Norte, distribuem-se por 46\% de escavações, $30 \%$ de acompanhamentos, $20 \%$ de prospecções, $3 \%$ de intervenções de conservação e restauro e $2 \%$ de levantamentos (registo), em proporção semelhante à observada a nível nacional.

$\mathrm{O}$ enquadramento institucional da actividade arqueológica na região regista é garantido por empresas de arqueologia (47\%), administração pública local (14\%), universidades e unidades de investigação (13\%), associações (7\%), administração pública central (4\%) e outros tipos de empresa (2\%). Os trabalhos arqueológicos sem entidade enquadrante representam $13 \%$ do total. As empresas de arqueologia surgem no final dos anos 9o do século XX, consolidam a sua presença até 2009 e registam ligeira quebra no último quinquénio. Situação idêntica ocorre

12. Consideraram-se os blocos cronológicos: Pré-História Antiga (Paleolítico, Mesolítico/Epipaleolítico), Pré-História Recente (Neolítico e Calcolítico), Proto-História (Idade do Bronze e Idade do Ferro), Romano, Medieval, Moderno, Contemporâneo e Diacrónico (centrados em problemáticas de evolução de longa duração cronológica e cultural). outro tipo de empresas e com as intervenções sem enquadramento institucional, igualmente associadas à arqueologia comercial. A Arqueologia municipal também regista tendência semelhante embora em volume mais reduzido. $\mathrm{O}$ volume de actividade arqueológica enquadrada pelas universidades e unidades de investigação portuguesas revela tendência estável, bem como a enquadrada pela administração pública central que registou nos anos 90 do século XX a sua fase mais dinâmica (Gráfico 13).

Os trabalhos arqueológicos realizados em meio urbano na região Norte representam $27 \%$ do total nacional, sendo a região com maior número de intervenções entre 2000 e 2004. A nível regional a actividade arqueológica urbana representa $38 \%$ do total (Bugalhão, 2018a, p. 34) e apresenta tendência de crescimento no período em estudo. Reconhecem-se duas fases: entre 1970 e 1994, a actividade decorre essencialmente em meio rural; entre 1995 e 2014, a actividade em meio urbano ganha preponderância crescendo chegando a suplantar a realizada em meio rural no último quinquénio (Gráfico 14). Em termos quantitativos destacam-se pelo elevado número de intervenções arqueológicas realizadas, as cidades do Porto, Braga, Chaves, Viana do Castelo, Penafiel, Vila Nova de Gaia e Guimarães (Bugalhão, 2018a, p. 34). Uma avaliação ainda preliminar revela que os trabalhos arqueológicos desenvolvidos em meio subaquático e/ou húmido ma região Norte representam $23 \%$ do total (Bugalhão, 2018b, p. 46).

$O$ financiamento da actividade arqueológica em Portugal durante o período em estudo ocorre principalmente sob dois formatos, o directo e o contratualizado. O primeiro refere-se à forma de financiamento tradicional: (i) no âmbito das instituições (públicas ou privadas) que se dedicam à actividade arqueológica com recursos próprios; (ii) ou através da atribuição de subsídios, bolsas e outro tipo de pacotes financeiros para a custear (sem transacção de natureza comercial envolvida). O segundo formato refere-se à arqueologia comercial (arqueologia contratual ou arqueologia sob contrato) na qual o financiamento decorre de um contrato de natureza comercial, podendo ocorrer em contexto empresarial ou liberal. Trata-se de financiamento indirecto, pois provém de fontes não destinadas directamente à Arqueologia, constituindo uma parcela de orçamentos de estudos, planos, projectos e obras no âmbito dos quais são impostos trabalhos arqueológicos preventivos, ao abrigo da aplicação do princí- 
pio do poluidor-pagador adaptado à gestão do património arqueológico (artigo 6. da Convenção de Malta e n.. 3 do artigo 79.. da Lei n.. $107 / 2001$, Lei Base do Património Cultural). Na região Norte, entre 1970 e 2014, o financiamento directo representa cerca de $36 \%$ e o financiamento indirecto no âmbito da arqueologia comercial representa cerca de $64 \%$, valores alinhados com os relativos ao todo nacional.

\section{ARQUEOLOGIA E ARQUEÓLOGOS NO NORTE DE PORTUGAL}

A região Norte do país desempenhou um papel muito relevante no ensino da Arqueologia em Portugal, quer ao nível técnico, através da Escola Profissional de Arqueologia do Freixo, quer, principalmente, a nível superior, através da Faculdade de Letras da Universidade do Porto. Esta faculdade desempenhou um papel pioneiro com a criação das licenciaturas em História, variante Arqueologia (1990) e em Arqueologia (1999) e do mestrado em Arqueologia (1989). No período em estudo, a Faculdade de Letras da Universidade do Porto é o estabelecimento de ensino superior português com maior número de diplomados em mestrado/2.. ciclo de Bolonha e doutoramento/ $3 .{ }^{\circ}$ ciclo de Bolonha. Também a Universidade do Minho regista um desempenho relevante nesta matéria, nomeadamente no que se refere aos estudos académicos sobre Arqueologia em meio urbano.

Entre os naturais da região Norte do país verifica-se, aparentemente, uma apetência pela Arqueologia ligeiramente inferior à registada a nível nacional. $\mathrm{O}$ número de mulheres arqueólogas nascidas no Norte é também proporcionalmente inferior. Contudo, estas duas realidades têm vindo a atenuar-se. No início do período em estudo, os arqueólogos nortenhos eram tendencialmente mais velhos, mas em 2014 eram já, em média, mais jovens, comparativamente com os valores nacionais. Ao longo das últimas décadas, os arqueólogos nortenhos são progressivamente mais qualificados; o número de titulares de mestrado é proporcionalmente elevado, mas são proporcionalmente menos frequentes os titulares de doutoramento. $\mathrm{O}$ amadorismo foi progressivamente abandonado entre os arqueólogos nascidos no Norte. Entre os profissionais, regista-se uma incidência superior de trabalho independente e de empresários; e uma incidência inferior de trabalho dependente e de bolseiros/investigadores. Neste grupo registam- -se também valores elevados de trabalho sem qualquer enquadramento institucional, mas um número muito elevado de arqueólogos trabalha em empresas de arqueologia e em municípios.

No Norte encontra-se sedeado um número significativo de instituições com actividade em Arqueologia, destacando-se os municípios, as empresas de arqueologia e as universidades e unidades de investigação. Entre 1970 e 2014, a actividade arqueológica portuguesa desenvolve-se de forma equilibrada em todas as regiões de Portugal continental, registando um forte crescimento (Bugalhão, 2011, p. 27), tanto em meio rural e subaquático, como, principalmente em meio urbano (Bugalhão, 2018a). A região Norte regista valores significativos nos projectos e trabalhos de investigação, especialmente sobre contextos proto-históricos e da pré-história recente. As intervenções de valorização e musealização de sítios arqueológicos é também especialmente relevante na região. Os trabalhos preventivos assumiram progressivamente prevalência quantitativa, nomeadamente no âmbito de processos de licenciamento e obras e de avaliação de impacte ambiental. As intervenções de emergência atingiram valores significativos nos anos 80 do século $\mathrm{XX}$. $\mathrm{O}$ enquadramento institucional desta actividade é bastante diversificado, destacando-se as empresas de arqueologia, a administração pública local e as universidades e unidades de investigação.

\section{BIBLIOGRAFIA}

ALMEIDA, Maria José (2007) - Inquérito Nacional à Actividade Arqueológica: uma segunda leitura sobre a actividade arqueológica nas autarquias portuguesas. Praxis Arqueológica - Revista Electrónica de Teoria, Metodologia e Política da Arqueologia. Porto. 2, pp. 129-169.

ARNAUD, José Morais, ed. (2013) - Memória e intervenção. 150 Anos da Associação dos Arqueólogos Portugueses. Lisboa: Associação dos Arqueólogos Portugueses, 110 p.

BUGALHÃO, Jacinta (2011) - Os desafios da Arqueologia portuguesa nas últimas décadas. Arqueologia e História. Lisboa, 6o-61, pp. 19-43.

BUGALHÃO, Jacinta (2016) - Arqueologia, Universidades e Ensino em números e em gráficos. Documento não publicado preparado no âmbito da Sessão "Arqueologia - Universidades e Ensino, em números e em gráficos”, organizada pela Secção de Arqueologia da Associação dos Arqueólogos Portugueses, em Lisboa, a 9 de Abril de 2016. Disponível em: https://www.academia.edu/37215410/Arqueologia_Universidades_e_Ensino_em_n\%C3\%BAmeros_e_em_gr\% 3 \%Arficos (acedido em 13 de Novembro de 2018). 
BUGALHÃO, Jacinta (2017) - Arqueólogos Portugueses. In ARNAUD, José Morais; MARTINS, Andrea, eds. - Arqueologia em Portugal / 2017 - Estado da Questão. Lisboa: Associação dos Arqueólogos Portugueses, pp. 19-31.

BUGALHÃO, Jacinta (2018a) - Arqueologia urbana, em Portugal, hoje. Revista Património. Lisboa. 5 (2017-2018), pp. 30-39.

BUGALHÃO, Jacinta (2018b) - A actividade arqueológica subaquática no quadro da Arqueologia Portuguesa. CulturAçores - Revista de Cultura. Angra do Heroísmo. 8 (Janeiro-Junho, 2018), pp.44-47.

BUGALHÃO, Jacinta (no prelo) - Gender divergence and convergence in Portuguese Archaeology. Actas do AGE Workshop 2017. Gender and Change in Archaeology, Lisboa, 19 e 20 de Outubro de 2017. Instituto de História Contemporânea, Grupo Ciência: Estudos de História Filosofia e Cultura Científica (Universidade de Évora), Faculdade de Ciências Sociais e Humanas da Universidade Nova de Lisboa, Secção de Arqueologia da Sociedade de Geografia de Lisboa e AGE, Archaeology and Gender in Europe. Archeaopress.

CENTENO, Rui; SOEIRO, Teresa; SANCHES, Maria de Jesus (2013) - Caminhos e encruzilhadas. O ensino e a investigação em Arqueologia na Faculdade de Letras da U.P. Revista da Faculdade de Letras. Ciências e Técnicas do Património (Homenagem a Armando Coelho Ferreira da Silva). Porto. XIII, pp. 31-48.

DIAS, Lino Tavares (1998) - A Escola Profissional de Arqueologia enquanto instituição de suporte para a investigação arqueológica. In SILVA, Maria Isabel; MAIA, Maria Isaura dos Santos; SOUSA, Maria José Carvalho e; PINTO, Paulo Costa, eds. (1998) - Encontros Cem anos de Arqueologia "O Archeólogo Português". Vila do Conde: Associação de Protecção do Património Arqueológico de Vila do Conde, pp. 37-40.

FABIÃO, Carlos (1999) - Um século de Arqueologia em Portugal - I. Al-Madan. Almada. II Série, 8, pp. 104-126.

FABIÃO, Carlos (2011) - Uma História da Arqueologia Portuguesa. Das origens à descoberta da Arte do Côa. Lisboa: Clube do Coleccionador dos Correios/CTT Correios de Portugal, $192 \mathrm{p}$.

JORGE, Susana Oliveira (2003) - A Faculdade de Letras da Universidade do Porto e a Pré-História do Norte de Portugal: notas para a história da investigação dos últimos vinte e cinco anos. In Os Reinos Ibéricos na Idade Média: livro de homenagem ao Professor Doutor Humberto Carlos Baquero Moreno, Porto: Universidade do Porto/Faculdade de Letras, vol. 3, pp. 1453-1482.

JORGE, Susana Oliveira; JORGE, Vítor Oliveira (1996) Women in Portuguese archaeology. Trabalhos de Antropologia e Etnologia. Porto. XXXVI, pp. 159-167.

JORGE, Vítor Oliveira (1986) - Sobre a importância de se organizar a arqueologia portuguesa por meio de projectos e de se definir uma hierarquia de competências de quem neles intervém. Arqueologia. Porto. 13 (Junho de 1986), pp. 2-5.

JORGE, Vítor Oliveira; MARQUES, Teresa (1992) - A Arqueologia nas Universidades. Al-Madan. Almada. II Série, 1, pp. 36-38.

LAGO, Miguel (2003) - Profissão: arqueólogo (na transição do milénio). In CARNEIRO, Sérgio, ed. - Nos 10 Anos da APA. Que Futuro para a Arqueologia Profissional? Porto: Associação Profissional de Arqueólogos, pp. 95-108.

LEMOS, Francisco Sande (1987) - As três idades da arqueologia portuguesa. Forum. Braga. 2, pp. 5-11.

LEMOS, Francisco Sande (2003) - Arqueologia em Portugal em tempo de crise. In CARNEIRO, Sérgio, ed. - Nos 10 Anos da APA. Que Futuro para a Arqueologia Profissional? Porto: Associação Profissional de Arqueólogos, pp. 49-55.

LEMOS, Francisco Sande (2007) - Memórias do Tempo recente... Al-Madan. Almada. II Série, 15, pp. 106-109.

MEIRELES, José (2006) - A Arqueologia na Universidade do Minho. Al-Madan. Almada. II Série, 14 (Dezembro de 2006), pp. 116-117.

PORDATA - Pordata, Base de Dados de Portugal Contemporâneo. Fundação Francisco Manuel dos Santos. Disponível em: http://www.pordata.pt/.

RAPOSO, Jorge (2006) - Bolonha e o Ensino da Arqueologia e de Áreas de Conhecimento Afins. Al-Madan. Almada. II Série, 14 (Dezembro de 2006), pp. 102-110.

RAPOSO, Jorge (2016) - Sítios Arqueológicos Portugueses Revisitados: 500 arqueossítios ou conjuntos em condições de fruição pública responsável. Al-Madan. Almada. II Série, 20 (Janeiro de 2016), pp. 70-196.

REAL, Fernando C. S. (1995) - A Arqueologia Portuguesa em mapas e números. In JORGE, Vítor Oliveira, ed. $-1 .{ }^{\circ}$ Congresso de Arqueologia Peninsular. Actas, VIII (Trabalhos de Arqueologia e Etnologia, XXXV: 4). Porto: Sociedade Portuguesa de Antropologia e Etnologia, pp. 19-40.

SILVA, António Manuel (2003) - A APA, a razão e sentido de uma associação profissional. In CARNEIRO, Sérgio, ed. - Nos 10 Anos da APA. Que Futuro para a Arqueologia Profissional? Porto: Associação Profissional de Arqueólogos, pp. 67-76.

SOEIRO, Teresa (2006) - Licenciatura em Arqueologia na Universidade do Porto: adequação ao "Processo de Bolonha”. Al-Madan. Almada. II Série, 14 (Dezembro de 2006), pp. 118-119. 


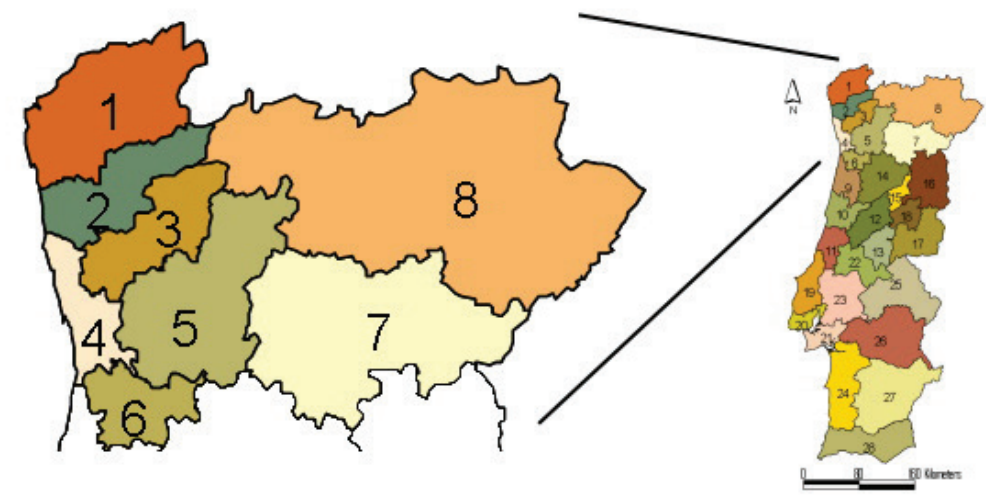

Figura 1

Diplomados em Arqueologia em estabelecimentos de ensino superior da região Norte por quinquénio 1975 - 2014

(valores estimados a tracejado)

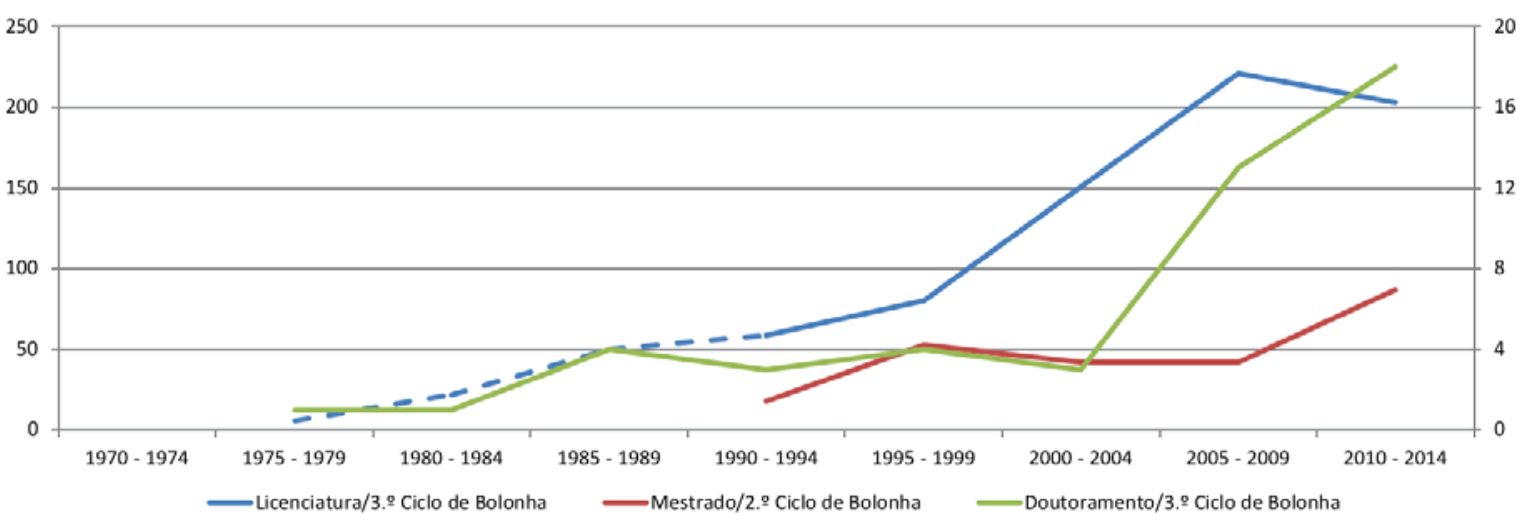

Gráfico 1

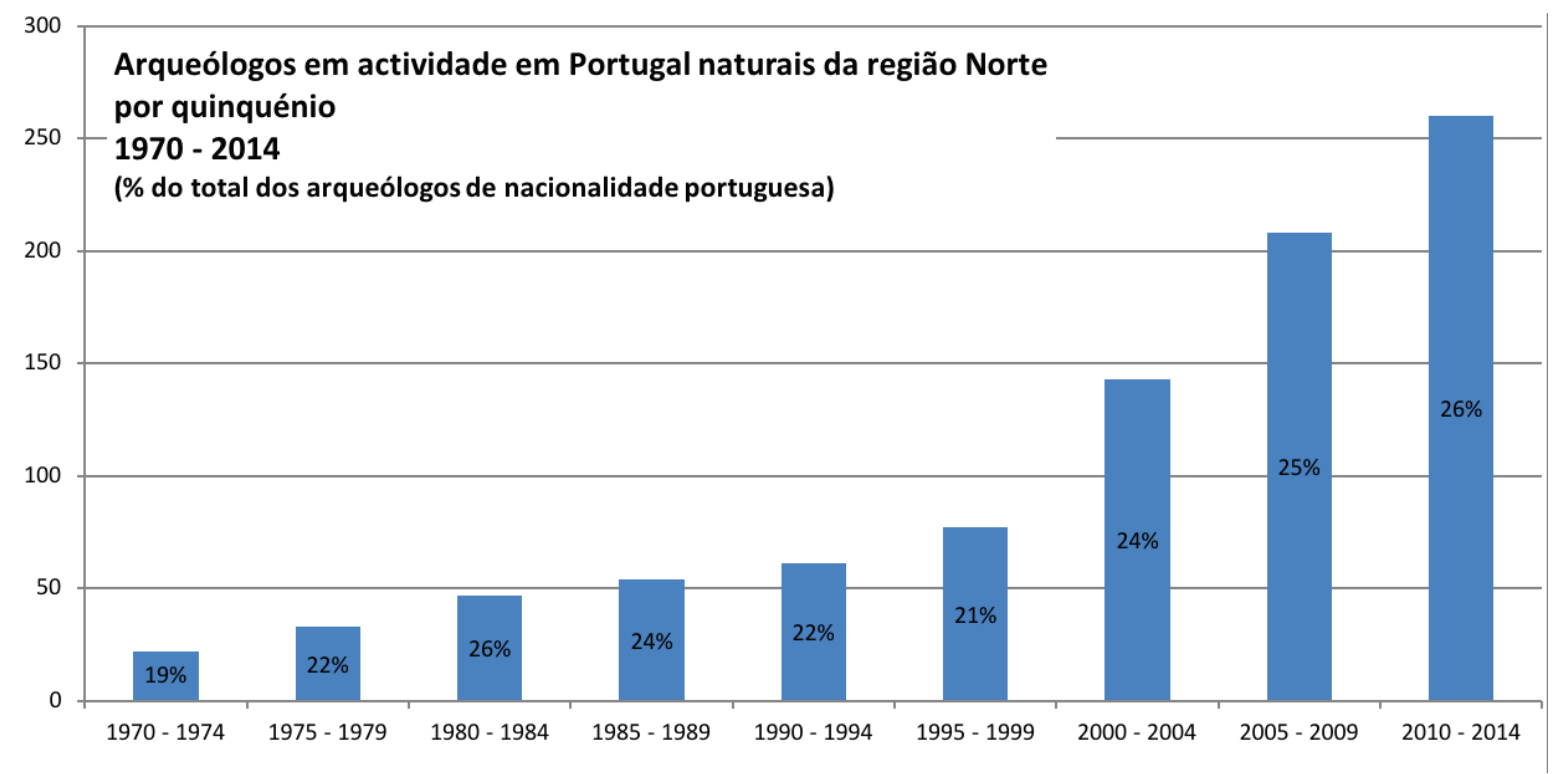

Gráfico 2 
Arqueólogos em actividade em Portugal naturais da região Norte

1970 - 2014

Sexo por quinquénio

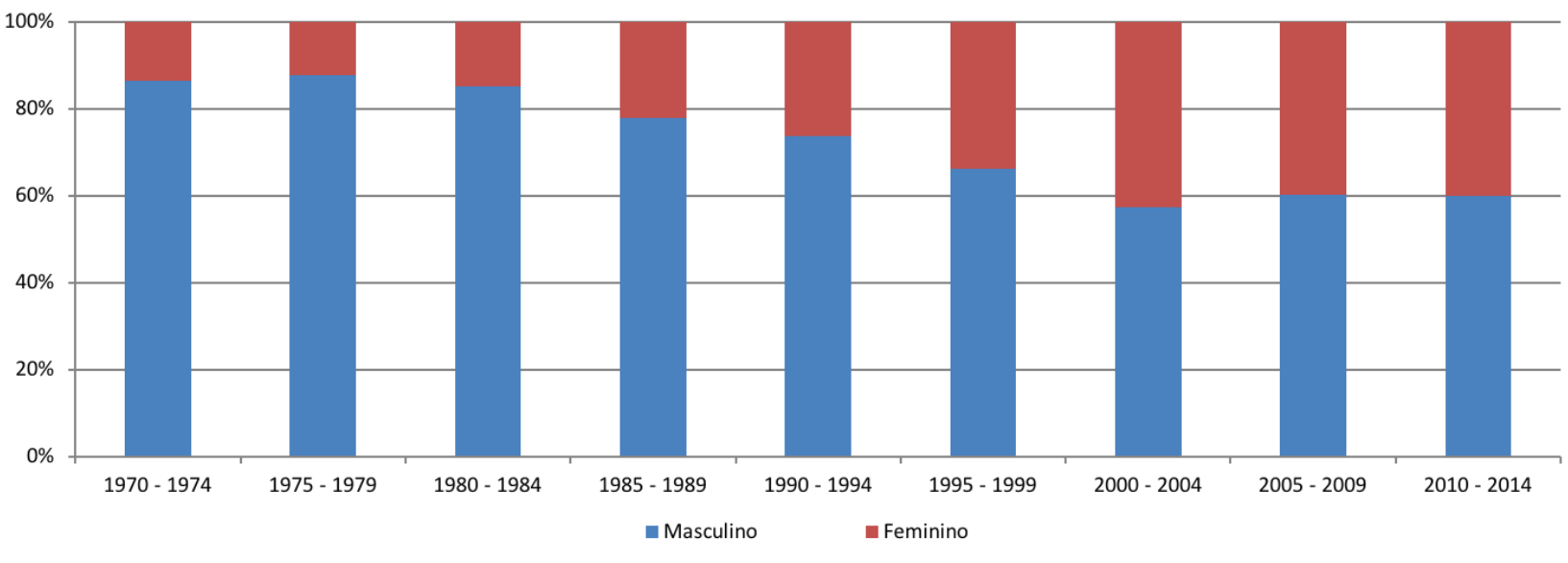

Gráfico 3

Arqueólogos em actividade em Portugal naturais da região Norte

1970 - 2014

Média etária por quinquénio

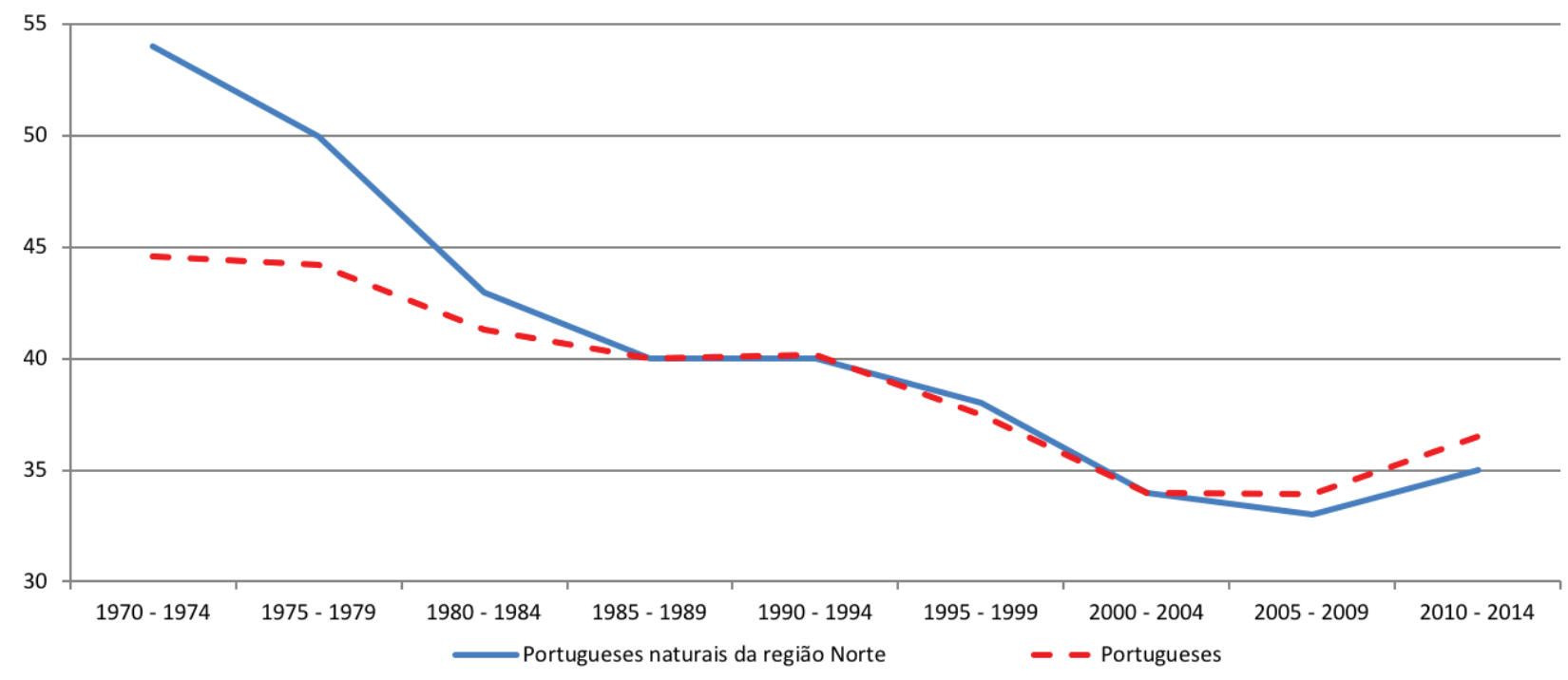

Gráfico 4 
Arqueólogos em actividade em Portugal naturais da região Norte

1970 - 2014

Habilitação académica no quinquénio

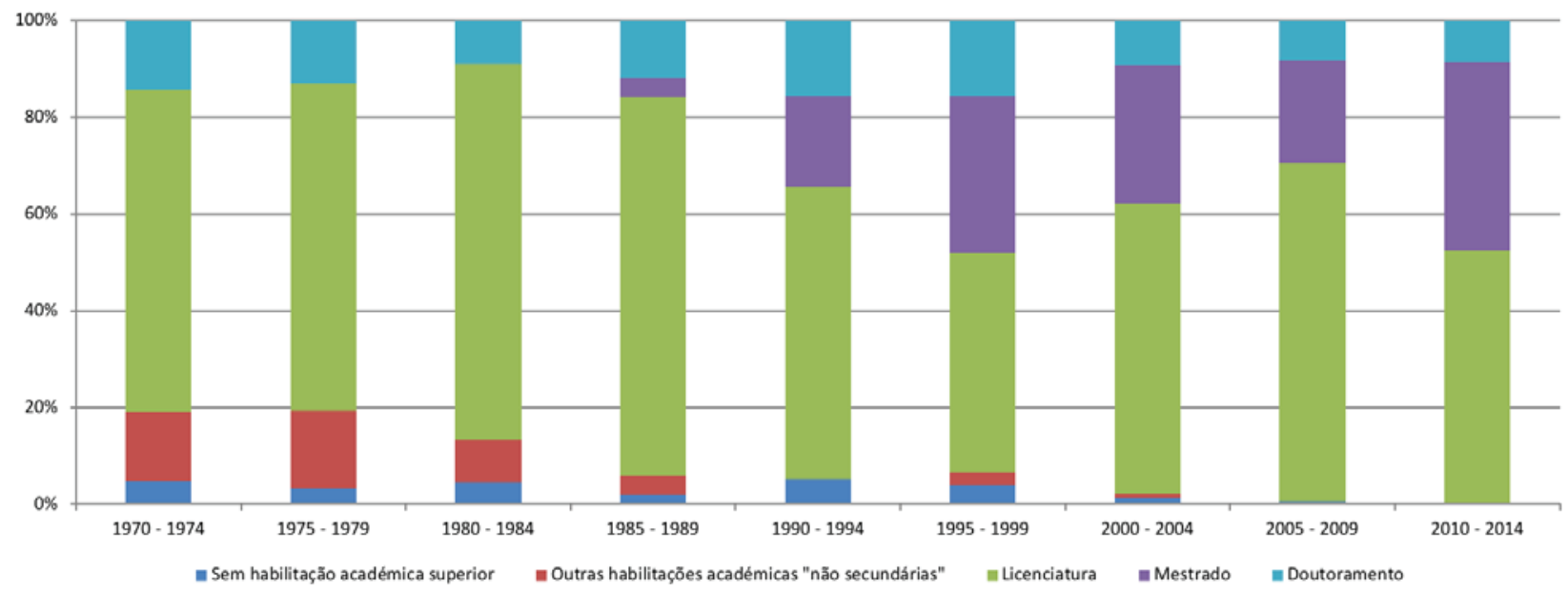

Gráfico 5

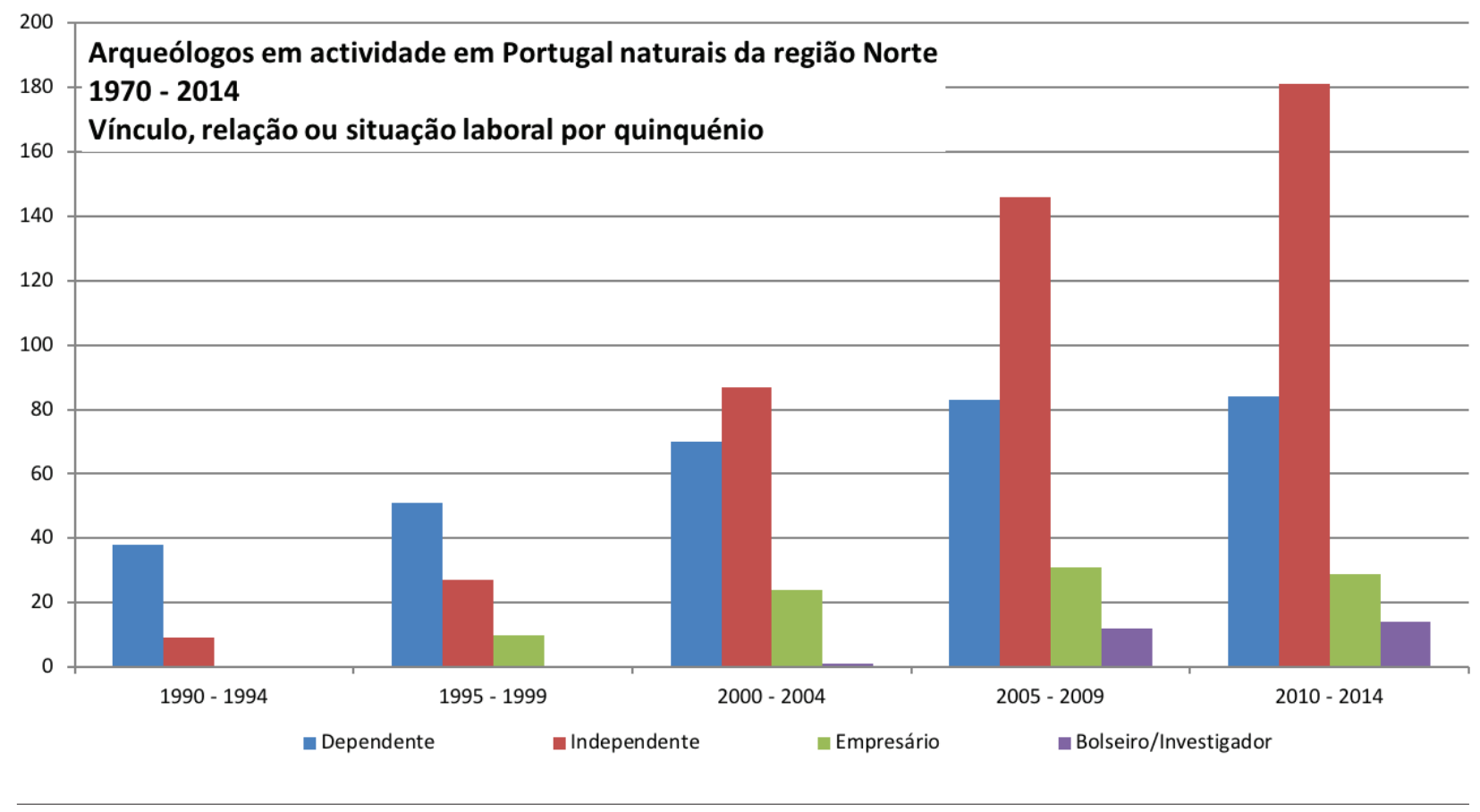

Gráfico 6 


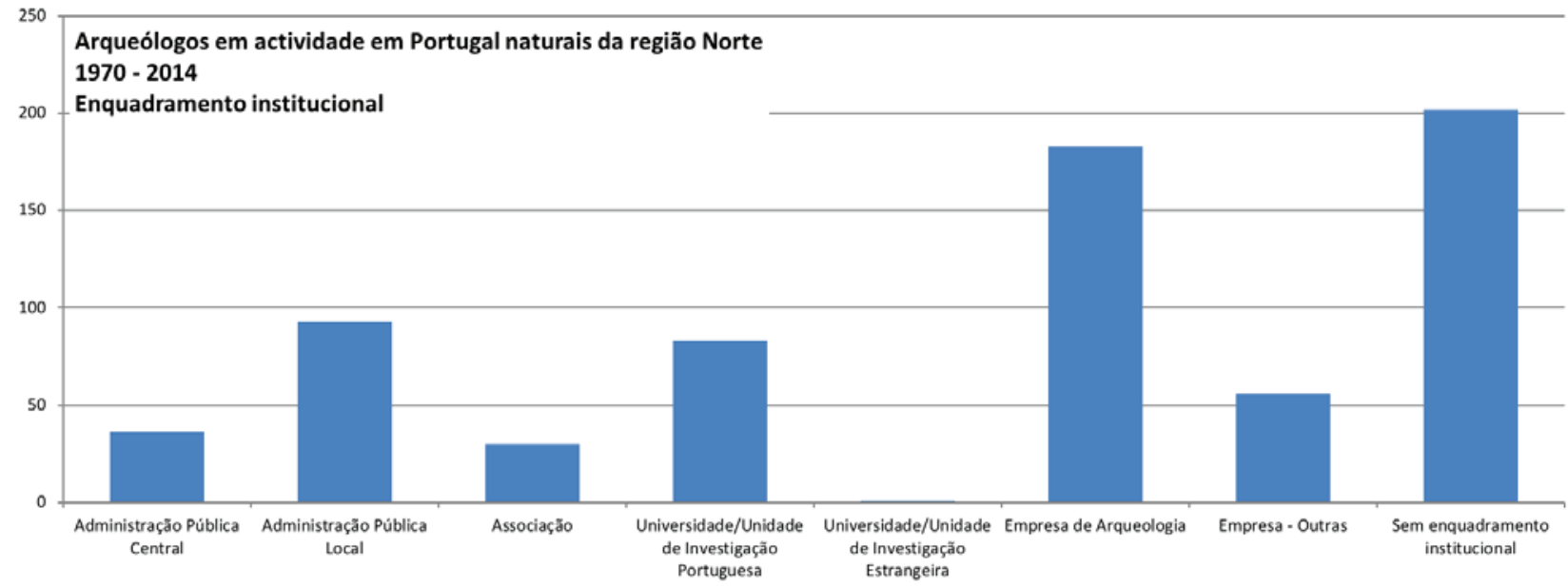

Gráfico 7

Instituições com actividade em Arqueologia sedeadas na região Norte

1970 - 2014

Tipo

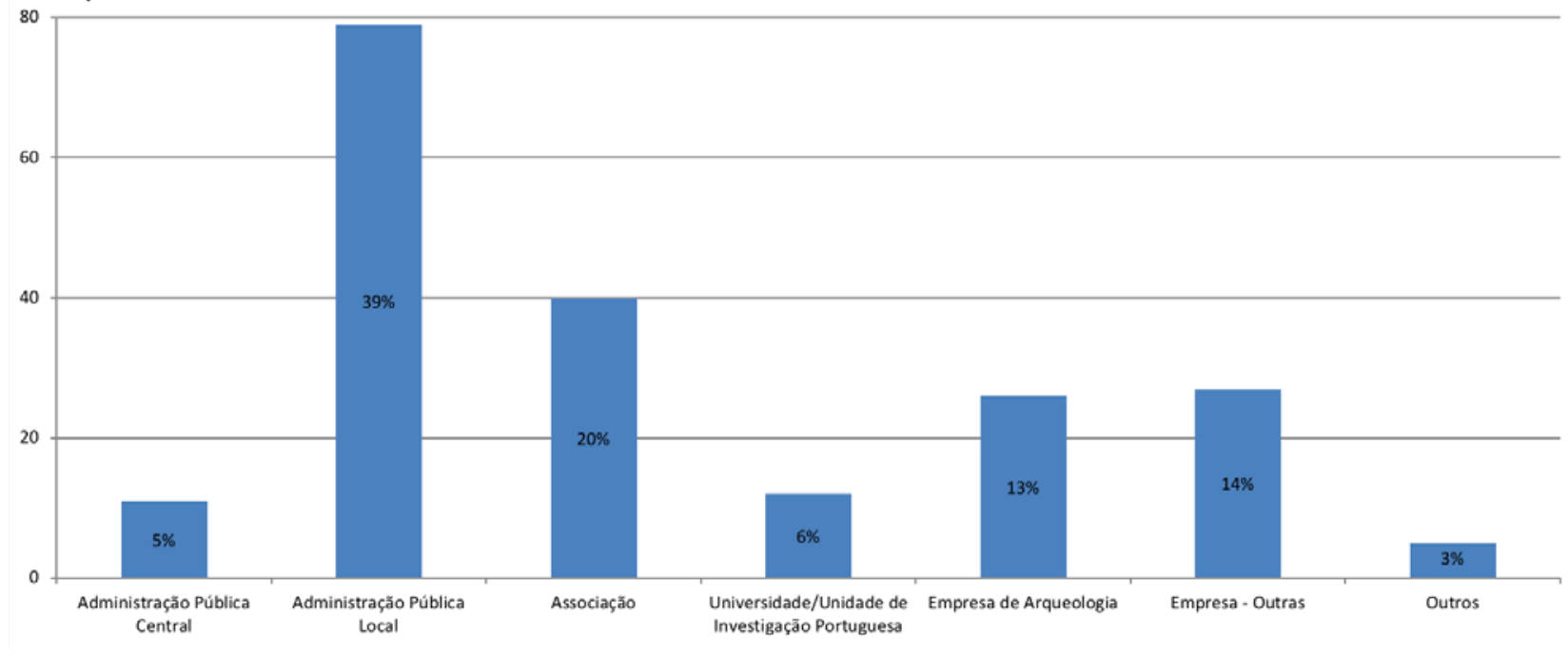

Gráfico 8 


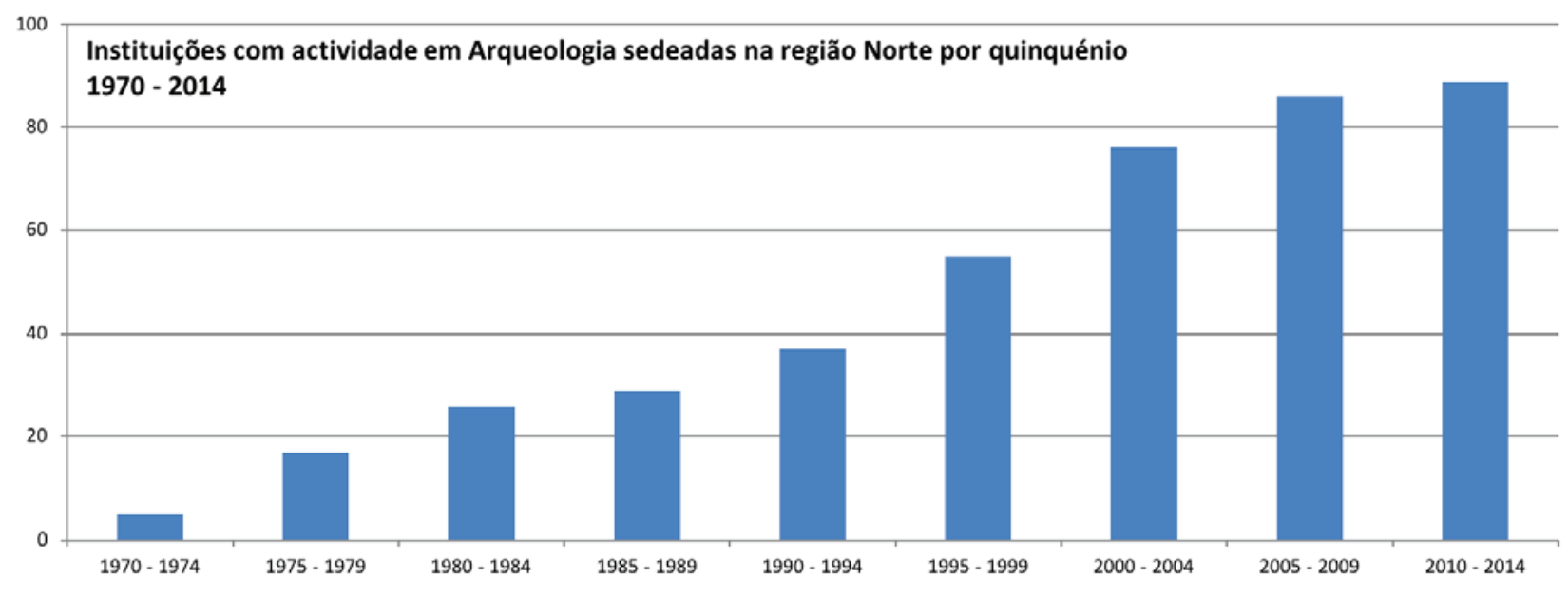

Gráfico 9

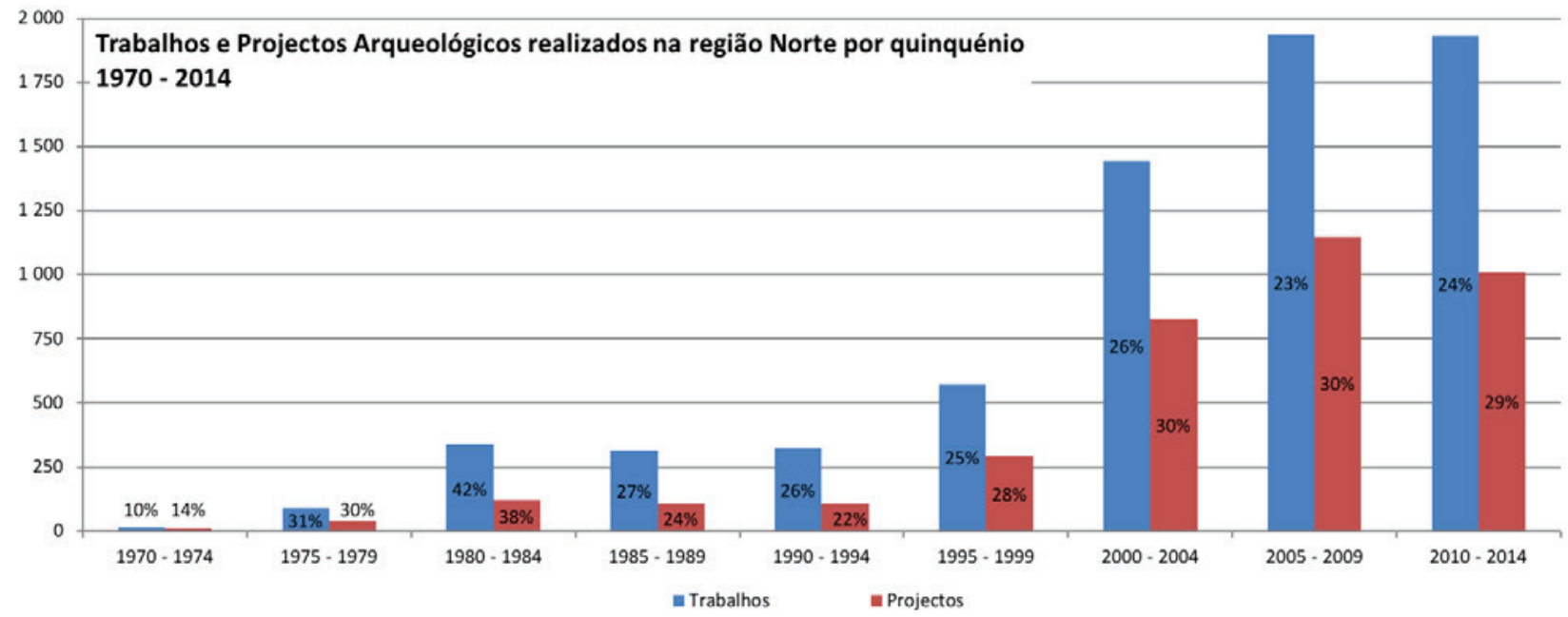

Gráfico 10 


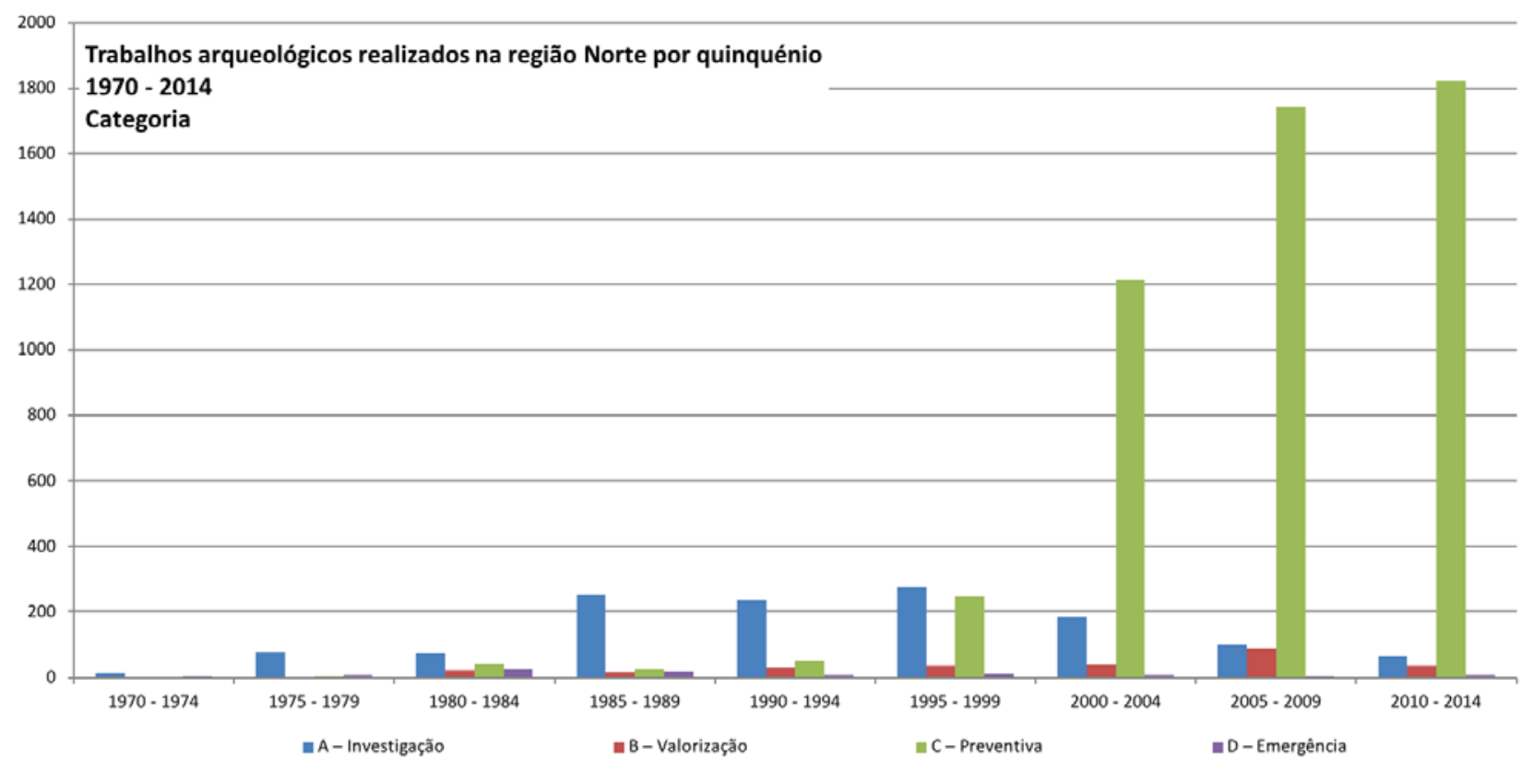

Gráfico 11

Projectos de Investigação desenvolvidos na região Norte

1970 - 2014

Período histórico

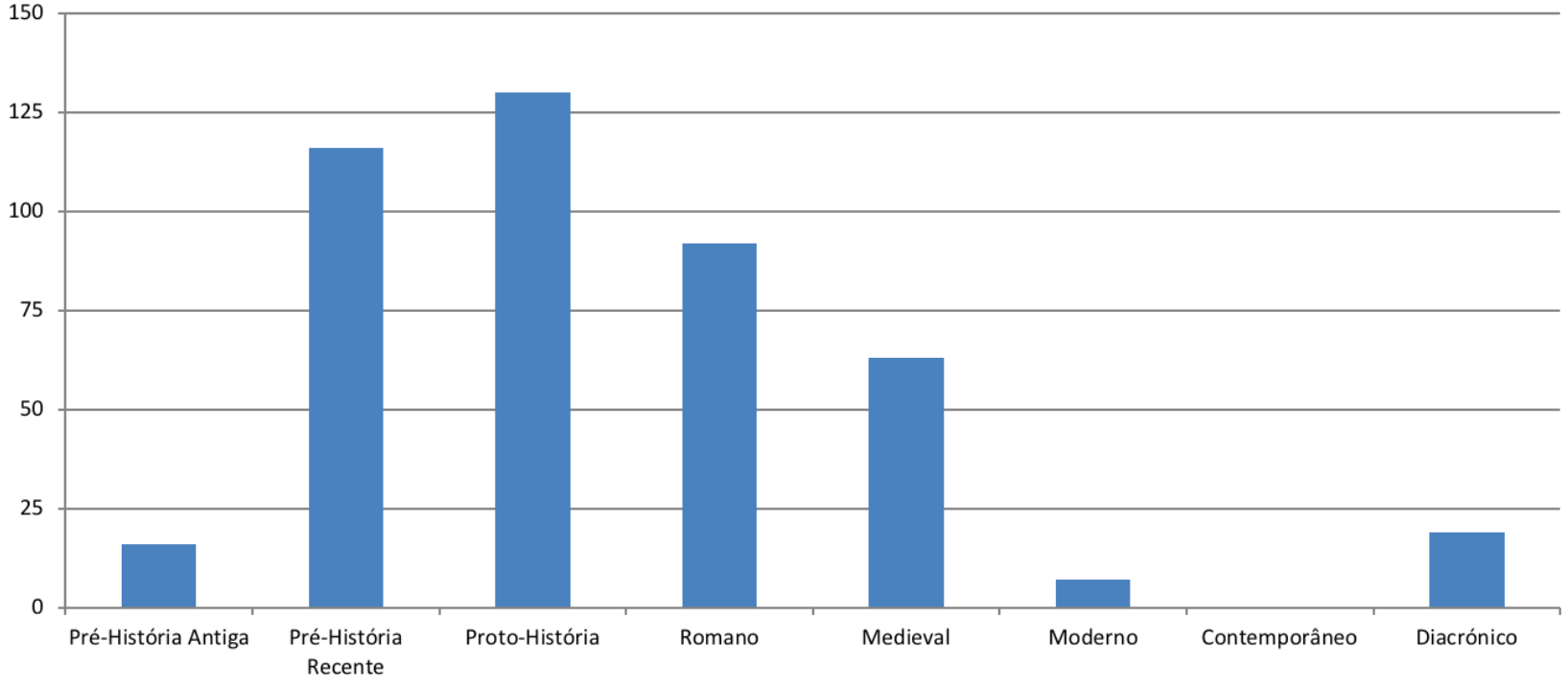

Gráfico 12 


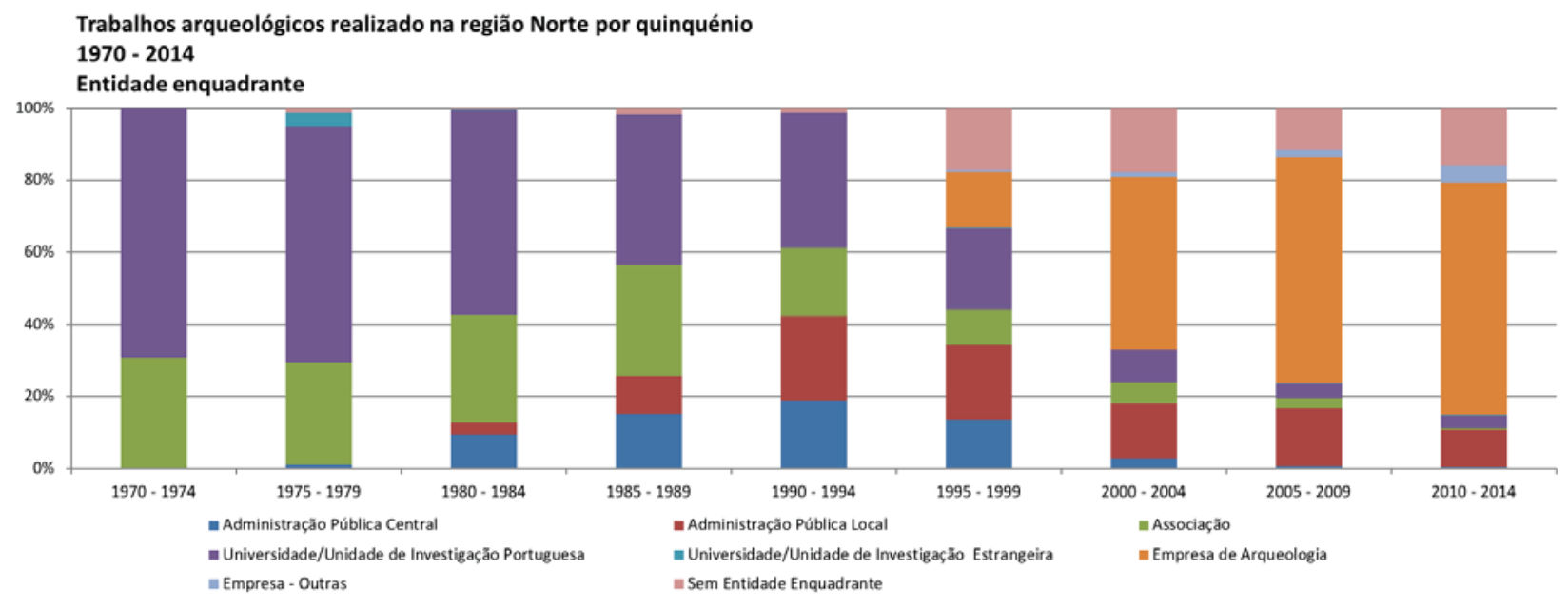

Gráfico 13

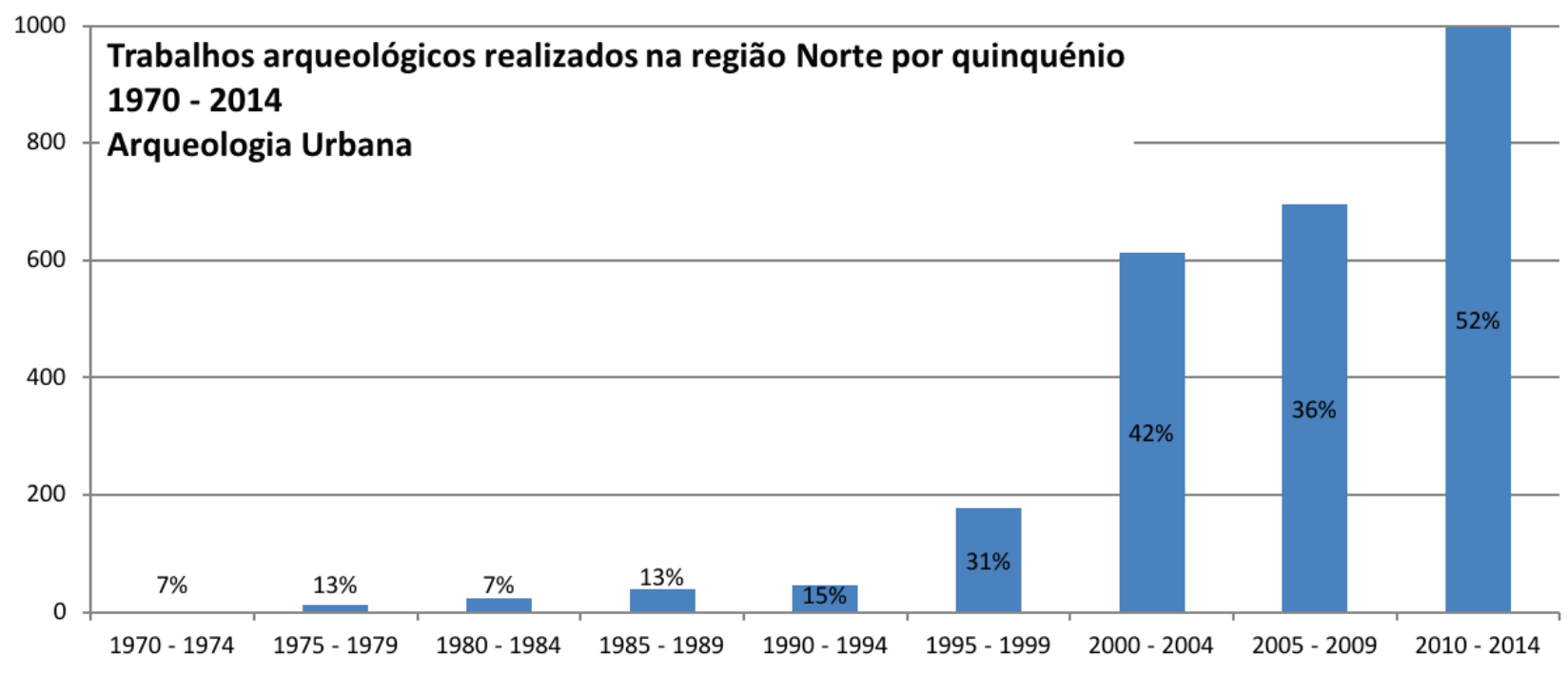

Gráfico 14 



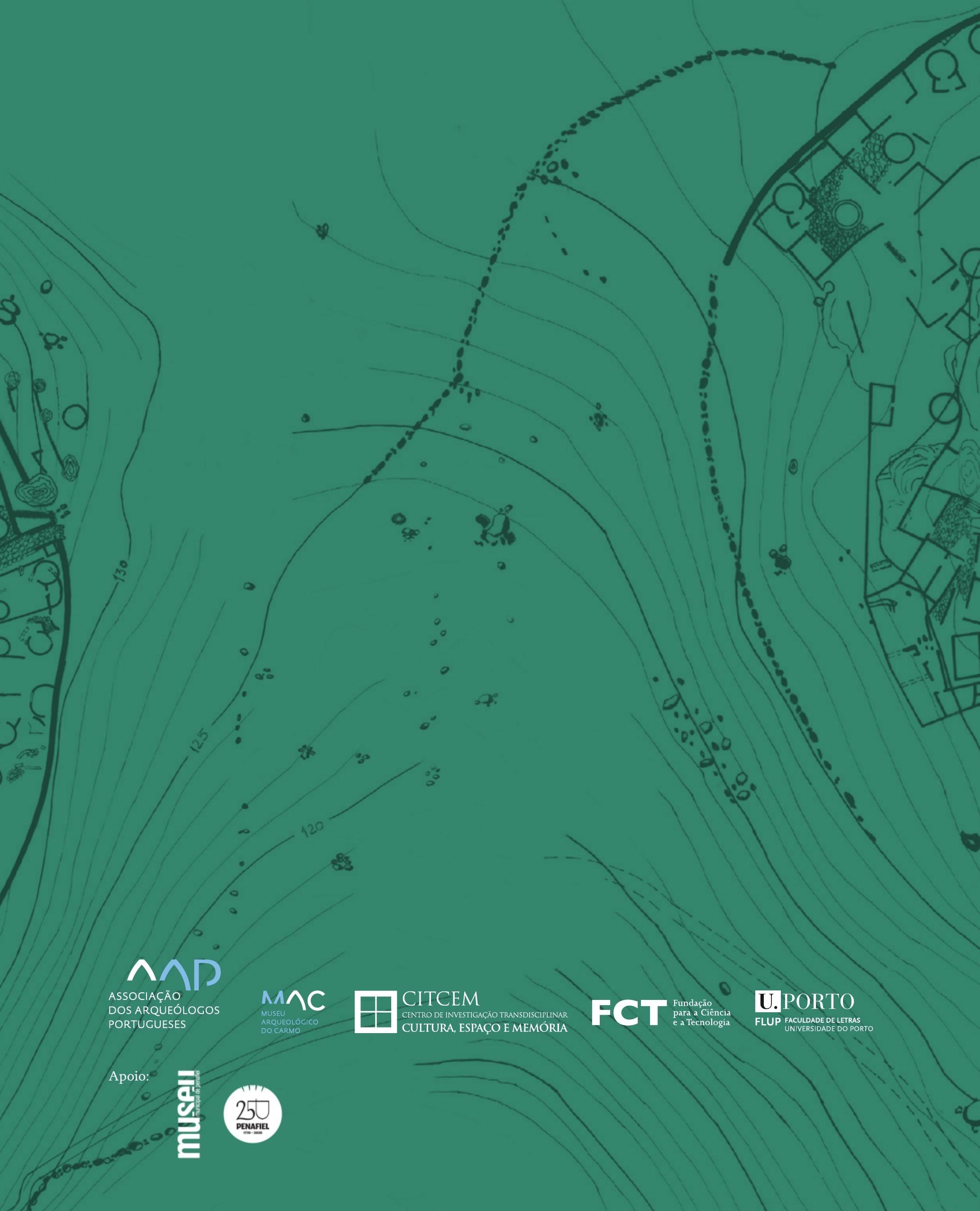

